\title{
DIGITAL BANKING DAN RISIKO OPERASIONAL (STUDI KASUS PADA NASABAH BANK CENTRAL ASIA DAN BANK RAKYAT INDONESIA)
}

\author{
Rizki Hartanto Tanic ${ }^{\mathbf{1}}$, Apriani Dorkas Rambu Atahau ${ }^{2 *}$ \\ ${ }^{12}$ Fakultas Ekonomika dan Bisnis Universitas Kristen Satya Wacana (UKSW) Salatiga \\ Jl. Diponegoro No. 52-60 Salatiga 50711, Indonesia \\ *Penulis Korespondensi; Email: 212015175@student.uksw.edu ${ }^{1}$, apriani@staff.uksw.edu ${ }^{2}$
}

\begin{abstract}
Abstrak
Seiring dengan perkembangan internet yang mengikuti pesatnya kemajuan teknologi, masyarakat membutuhkan pembayaran yang cepat dan efisien karena semakin banyaknya transaksi keuangan. Internet banking merupakan salah satu produk bank digital banking yang memfasilitasi transaksi keuangan. Namun penggunaan internet banking tidak lepas dari risiko operasional yang akan terjadi. Sebagai salah satu risiko bank, risiko operasional memegang peranan penting dalam penerapan digital banking. Oleh karena itu, penting untuk mempelajari persepsi nasabah terhadap risiko operasional bank dalam memberikan layanan perbankan digital. Populasi dalam penelitian ini adalah nasabah Bank Central Asia (BCA) dan Bank Rakyat Indonesia (BRI) yang menggunakan layanan internet banking. Sampel yang diambil dalam penelitian ini adalah 100 responden dari Bank Central Asia dan 100 responden dari Bank Rakyat Indonesia di wilayah tersebut dan teknik yang digunakan adalah purposive sampling. Teknik analisis yang digunakan adalah analisis deskriptif kuantitatif. Analisis ini meliputi uji beda rata-rata, uji validitas, dan uji reliabilitas. Diproses menggunakan program SPSS versi 20. Temuan menunjukkan bahwa kedua bank memiliki risiko operasional yang rendah menurut nasabah yang disurvei. Meskipun BCA dinilai memiliki risiko operasional yang lebih rendah dibandingkan BRI, namun beberapa area seperti risiko sistem perlu mendapat perhatian lebih.
\end{abstract}

Kata kunci: Risiko hukum, risiko proses internal, risiko manusia, risiko sistem.

\begin{abstract}
Along with the development of the internet which has followed the rapid advances in technological development, people need fast and efficient payments due to the increasing number of financial transactions. Internet banking is one of the digital banking bank products that facilitate financial transactions. However, the use of internet banking cannot be separated from operational risks that will occur. As one of the bank risks, operational risk plays an important role in the implementation of digital banking. Hence, it is important to study the customer perception of banks' operational risk in providing digital banking services. The population in the study were customers of Bank Central Asia (BCA) and Bank Rakyat Indonesia (BRI) who used internet banking services. The samples taken in this study were 100 respondents from Bank Central Asia and 100 respondents from Bank Rakyat Indonesia in the area and the technique used was purposive sampling. The analysis technique used is quantitative descriptive analysis. This analysis included the average difference test, validity test, and reliability test. It was processed using the SPSS program version 20. The findings showed that both banks had low operational risks according to their surveyed customers. Although BCA was perceived to have lower operational risks than BRI, some areas such as system risks needed more attention.
\end{abstract}

Keywords: Legal risks, internal process risks, human risks, system risks.

\section{Pendahuluan}

Perkembangan teknologi informasi yang meningkat drastis dan perubahan pola hidup masyarakat, maka permintaan dari nasabah juga akan terus meningkat dan membuat perbankan harus bisa 
memenuhi permintaan para nasabahnya. Perbankan saat ini sudah mulai untuk memperluas layanannya supaya nasabah bisa mendapatkan berbagai macam layanan secara mandiri (self-service) tanpa perlu nasabah mengunjungi kantor bank untuk melakukan registrasi, macam-macam transaksi (tunai, pembayaran, transfer) dan berbagai layanan lainnya termasuk penutupan rekening, layanan digital ini disebut sebagai "digital banking". Layanan ini mempunyai tujuan untuk menaikan mutu pelayanan bank kepada nasabah. Penerapan perbankan online di Indonesia sejalan dengan meningkatnya pengguna perangkat seluler yang telah menjadi bagian dari gaya hidup orang, melihat kondisi tersebut pihak perbankan memberikan akses layanan yang lebih mudah kepada nasabahnya seperti pembukaan rekening, transfer, pembayaran tagihan, atau perencanaan keuangan lainnya semuanya digunakan dengan menggunakan sistem online (Sakti et al., 2018).

Salah satu fasilitas yang diberikan bank kepada nasabah untuk mempermudah melakukan aktivitas perbankan adalah teknologi internet banking. Nasabah dapat melakukan berbagai kegiatan perbankan hanya perlu terhubung dengan koneksi internet (www.bi.go.id). Jenis teknologi perbankan yang digunakan adalah Autometed Teller Machine (ATM), Banking Application System, dan Internet Banking. Otoritas Jasa Keuangan (OJK) mengungkapkan, saat ini jumlah pengguna e-banking (phone banking, internet banking, SMS banking, dan mobile banking) meningkat 270\%, dari 13,6 juta nasabah di tahun 2012 naik 50,4 juta di tahun 2016. Selain itu frekuensi jumlah transaksi pengguna e-banking meningkat $169 \%$, dari yang semula 150,8 juta transaksi di tahun 2012 menjadi 405,4 juta transaksi di tahun 2016 (Fuad, 2017). Pemanfaatan perkembangan teknologi dengan menghadirkan layanan perbankan dalam bentuk internet banking. Layanan penggunaan internet banking pada UMKM telah diteliti antara lain oleh Nugraha dan Atahau (2018), hasil penelitian menyatakan bahwa hubungan antara kepercayaan, risiko, dan model penerimaan teknologi dengan perilaku transaksi dan internet banking dapat dimediasi oleh minat pelanggan. Di dunia perbankan penggunaan teknologi informasi dan komunikasi relatif lebih maju jika dibandingkan dengan sektor lainnya.

Walaupun internet banking memberikan keuntungan pada dunia perbankan tidak memungkinkan bahwa internet banking juga bisa menimbulkan tindak kejahatan dari oknum-oknum yang tidak bertanggung jawab. Bisa dilihat contoh pada kasus bank Bank central Asia (BCA), terjadinya penipuan registrasi dengan menggunakan website palsu yang begitu mirip dengan alamat situs resminya BCA dan juga nasabah BCA mengalami pembobolan rekening dengan menggunakan fitur klik BCA.

Bank akan dikatakan aman jika bank tersebut bisa menjalankan fungsi-fungsinya dengan baik artinya, bank yang aman adalah bank yang mampu memberi rasa percaya kepada masyarakat, dan menjalankan fungsi intermediasi dengan baik, serta membantu kelancaran lalu lintas pembayaran, termasuk kebijakan moneter. Berbagai aktivitas yang dijalankan oleh bank akan berpeluang untuk menghasilkan keuntungan (income). Upaya perbankan menghasilkan keuntungan/profit tidak dapat dilepaskan dari kemampuannya untuk mengelola risiko. Sebagaimana diketahui risiko sebagai fluktuasi hasil akibat ketidakpastian masa depan mengandung dimensi positif dan negatif. Dalam hal terjadi keuntungan, maka fluktuasi hasil yang tinggi menggambarkan peluang keuantungan yang besar pula. Namun dalam hal terjadi kerugian, maka fluktuasi tinggi mengarah pada kerugian yang besar pula. Oleh karena itu dalam konteks manajemen risiko perbankan, dilakukan berbagai upaya untuk memperkecil efek negative dari ketidakpastian masa depan (Cahyaningrum \& Atahau, 2020).

Menurut Peraturan Bank Indonesia No. 11/25/PBI/2009 tentang Perubahan atas PBI No.5/8/ PBI/2003 tentang Penerapan Manajemen Risiko bagi Bank Umum atau Bank Konvensional wajib menerapkan Manajemen Risiko yang mencakup 8 risiko, yaitu risiko likuiditas, risiko kepatuhan, risiko kredit, risiko hukum, risiko strategik, risiko reputasi, risiko operasional, dan risiko pasar. Manajemen risiko yang terkait dengan risiko operasional ini dikenal sebagai manajemen risiko operasional. Seiring dengan itu, terdapat kebutuhan akan pemahaman yang memadai dan komprehensif mengenai manajemen risiko operasional karena banyaknya Penipuan, pembobolan dan website palsu.

Risiko operasional merupakan risiko yang mempengaruhi semua kegiatan usaha karena merupakan suatu hal yang inherent dalam pelaksanaan suatu proses atau aktivitas operasional. Pengguna layanan bank tentu harus berhati-hati dalam menggunakan layanan tersebut, karena terdapat oknumoknum yang tidak bertanggung jawab yang merencanakan kejahatan terkait dengan layanan-layanan tersebut dan mengatasnamakan bank.

Manajemen risiko menjadi faktor yang cukup penting dalam pengelolaan suatu bank. Lembaga keuangan tentunya sudah harus memikirkan cara-cara dalam memitigasi risiko-risiko yang akan diala- 
mi di masa mendatang. Hal terpenting dalam menerapkan manajemen risiko yaitu dengan menjalankan prosedur yang sesuai dan melakukan pengelolaan risiko, sehingga kegiatan usaha bank dapat berjalan dengan kondusif. Mengenai kemungkinan terjadinya kerugian yang dialami oleh bank di masa mendatang, dan bank dapat mengambil keputusan yang sesuai berdasarkan informasi, dan informasi tersebut dapat digunakan sebagai tolak ukur untuk kinerja bank, maka penerapan manajemen risiko sangat berguna bagi bank sebab dapat memberikan gambaran kepada pengelola bank.

Berdasarkan latar belakang penelitian yang diuraikan, maka tujuan dari penelitian ini untuk mengetahui risiko operasional digital banking dari sudut pandang nasabah Bank Central Asia (BCA) dan Bank Rakyat Indonesia (BRI). Sebagai bank papan atas yang tergolong dalam kategori BUKU IV, BCA dan BRI memiliki reputasi yang bagus dan pangsa pasar yang luas. Selain itu kedua bank tersebut memiliki kecanggihan sistem informasi yang dibuktikan dengan kepemilikan satelit oleh BRI dan keragaman berbagai produk layanan berbasis teknologi pada BCA. Pemilihan BRI mewakili milik bank pemerintah sedangkan BCA mewakili bank milik swasta. Adapun rumusan masalah penelitian ini adalah eksplorasi persepsi nasabah BCA dan BRI terhadap risiko operasional digital banking. Penelitian ini diharapkan dapat menjadi bahan rekomendasi bagi pihak manajemen perbankan dalam mengambil langkah terkait praktik manajemen risiko operasional digital banking, sehingga bank dapat memitigasi kemungkinan risiko yang akan terjadi di masa mendatang.

\section{Kajian Teoritis dan Hipotesis}

Layanan perbankan digital atau "Digital Banking" merupakan layanan/aktivitas perbankan melalui kantor bank yang dituju dengan memanfaatkan fasilitas elektronik/digital milik bank dan/atau melalui perangkat digital yang dijalankan secara mandiri oleh nasabah yang kemungkinan calon nasabah dan/atau nasabah untuk memperoleh penjelasan, berkomunikasi, pendaftaran untuk membuka rekening, transaksi perbankan dan menutup rekening, termasuk mendapatkan informasi yang lainnya dan transaksi di luar produk perbankan, contohnya nasihat keuangan (financial advisory), investasi, transaksi e-dagang (e-commerce), dan kepentingan lainnya dari nasabah bank. Berikut beberapa layanan perbankan digital.

Menurut penelitian Nasri dan Charfeddine (2012) persepsi mengenai kenyamanan penggunaan terhadap sikap menggunakan teknologi dapat berpengaruh positif. Mengenai internet banking, sikap mengacu pada dampak positif atau negatif dari penggunaan layanan internet banking sebagai alat pembayaran atau transaksi lainnya.

Internet banking adalah bentuk dari suatu pemanfaatan media internet oleh bank guna mempromosikan serta melaksanakan transaksi secara online, baik dari produk konvensional maupun yang baru. Menurut Nugraha dan Atahau (2018), Technology Acceptance Model (TAM) sudah banyak digunakan dalam penelitian sistem informasi dengan tujuan untuk mengetahui reaksi pengguna terhadap sistem informasi. Menurut Davis (1989) Technology Acceptance Model (TAM) merupakan teori sistem informasi yang membuat model tentang bagaimana pengguna mau menerima dan menggunakan teknologi. Model ini mengusulkan bahwa ketika pengguna ditawarkan untuk menggunakan suatu sistem yang baru, sejumlah faktor mempengaruhi keputusan mereka tentang bagaimana dan kapan akan menggunakan sistem tersebut, khususnya dalam hal usefulness, ease of use, dan faktor eksternal terhadap kepercayaan, sikap dan tujuan penggunaan.

Penawaran pelayanan kepada nasabah terkait internet banking memiliki tiga tahap, antara lain: (1) layanan informasi (informational) berupa website terkait informasi jasa keuangan, (2) komunikasi (communication) nasabah dan bank dapat berkomunikasi dengan fasilitas yang ada di website, (3) transaksi (transactttional/advance) nasabah dapat melakukan transaksi-transaksi keuangan (transfer dana, pengecekan saldo dan lain sebagainya untuk jenis pembayaran).

Berbagai jenis internet banking yang meliputi transfer dana, informasi saldo, mutasi rekening, informasi nilai tukar, Pembayaran tagihan (contoh: credit card, telepon, listrik), Pembelian (contoh: pulsa, tiket kereta/pesawat, hotel), dapat diakses nasabah dalam transaksi perbankan (financial dan non-financial) menggunakan komputer yang sudah terhubung dengan jaringan internet bank tertentu. 


\section{Risiko Operasional}

Adanya beberapa kegiatan usaha bank yang mengalami peningkatan, peningkatan tersebut membuat perbankan Indonesia mulai dihadapkan dengan berbagai macam risiko kompleks, sehingga bank dituntut untuk berperan penting dalam meningkatkan kebutuhan dalam menerapkan manajemen risiko dan memperkecil risiko terkait dengan kegiatan usaha perbankan (Cahyaningrum \& Atahau, 2012). Risiko adalah potensi kerugian yang terjadi akibat dari suatu peristiwa tertentu. Risiko perbankan merupakan suatu kejadian potensial, baik yang dapat diperkirakan maupun yang tidak dapat diperkirakan dan akan memberikan dampak negatif terhadap bank itu sendiri (Fasa, Saefullah, \& Wati, 2016).

Menurut Peraturan Bank Indonesia No. 11/22/PBI/2010 mengenai Perubahan atas PBI Nomor 5 /8/PBI/2003 tentang Penerapan Manajemen Risiko, risiko merupakan konsekuensi dari kerugian yang ditimbulkan oleh suatu peristiwa (events) tertentu, sedangkan manajemen risiko didefinisikan sebagai susunan metodologi dan prosedur yang mempunyai manfaat dalam hal mengobservasi, mengukur, mengamati dan mengendalikan risiko-risiko aktivitas usaha bank. Berikut merupakan jenis risiko yang harus dikelola dengan baik oleh bank.

\section{Tabel 1}

\section{Jenis Risiko Operasional}

Jenis Risiko

- Pelanggan tidak dapat bertransaksi karena lupa PIN atau ID pengguna.

- Tidak adanya prosedur dan proses bisnis yang jelas.

- Proses pengendalian aktivitas yang telah ada namun belum dilaksanakan dengan baik.

- Kata sandi yang terlalu rumit.

- Proses yang kurang efektif.

- Kesalahan ketika menginput data yang diakibatkan oleh kurangnya informasi mengenai prosedur yang benar.

- Situasi politik yang mengarah pada kerusuhan atau demonstrasi.

- Adanya bencana alam dalam skala nasional.

- Pencurian informasi Bank oleh pelanggan/pihak internal/pihak eksternal.

- Pelanggan tidak dapat mengakses transaksi melalui online perbankan karena tidak adanya jaringan atau masalah dengan penyedia sistem (turun).

- Sistem bank rentan terhadap virus atau malware.

- Pengiriman SMS atau Email sebagai bukti transaksi tidak dapat dikirim.

- Tidak dapat menyimpan data pelanggan dan mencadangkannya.

- Pencurian ID pengguna pelanggan oleh pihak eksternal.

- Pelaku penipuan bertindak atas nama klien dan secara tidak sah mengakses akun pelanggan.

- Pihak eksternal melakukan penipuan yang bertindak atas nama Bank dan meminta ID pengguna atau Kata Sandi pelanggan.

- Pelaku bekerja sama dengan karyawan Bank untuk menghubungkan ATM dengan nomor rekening pribadi atau akun lain.

- Pelaku penipuan menggunakan domain lain untuk mengakses sistem Bank.

- Pelanggan telah melakukan setoran awal untuk membuka akun, tetapi pembukaan akun ditolak oleh Bank.

- Sistem Bank dibajak oleh pihak eksternal.

- Karyawan membuka akun palsu dengan pelanggan untuk mendapatkan insentif.

- Pelanggan tidak dapat memberikan kartu identitas dan kewajiban dokumen lainnya.

- Pelanggan tidak menerima kartu ATM.

- Bank tidak memiliki cadangan data pelanggan.

- Pelanggan tidak dapat melakukan transaksi melalui ATM.

- Pelanggan menolak transaksi yang telah dilakukan.

Sumber: Sakti et al., 2018

Risiko operasional merupakan risiko yang terjadi karena tidak bekerjanya proses internal, $h u$ man error, kegagalan sistem, serta terdapat adanya masalah dari pihak eksternal yang akan menggang- 
gu kinerja operasional bank. Pengendalian risiko operasional harus menyediakan kepastian, sehat dalam operasi dan menghasilkan pelaporan yang dapat dipercaya. Timbulnya risiko operasional disebabkan oleh tidak cukupnya kontrol internal dan internal audit yang dipakai pada setiap perbankan, sehingga jika terjadi kesalahan tidak dapat diselesaikan dengan cepat. Penelitian sebelumnya Sakti et al. (2018) mengatakan bahwa ada 26 tipe-tipe risiko operasional terdapat di kantor pusat bank XYZ seperti bisa dilihat pada Tabel 1 .

\section{Metode Penelitian}

Menurut Darmadi (2013) metode penelitian adalah suatu cara ilmiah untuk mendapatkan data dengan tujuan kegunaan tertentu. Cara ilmiah berarti kegiatan penelitian itu didasarkan pada ciri-ciri keilmuan yaitu rasional, empiris, dan sistematis. Metode yang digunakan dalam penelitian ini adalah deskriptif. Metode ini digunakan untuk mengetahui risiko operasional, digital banking pada Bank Central Asia dan Bank Rakyat Indonesia.

\section{Jenis dan Sumber Data Penelitian}

Desain penelitian ini menggunakan pendekatan kuantitatif. Populasi yang diteliti dalam penelitian ini adalah nasabah bank BCA dan BRI. Sumber data yang akan digunakan dalam penelitian ini berupa data primer. Data primer merupakan data yang didapatkan secara langsung, yakni dengan membagikan kuesioner kepada nasabah bank.

\section{Populasi dan Sampel}

Populasi dalam penelitian ini adalah seluruh nasabah BCA dan BRI yang tidak diketahui jumlahnya. Jumlah sampel yang diteliti ditentukan dengan menggunakan teknik pengambilan sampel nonprobability sampling, yaitu purposive sampling. Kriteria yang dipilih adalah nasabah BCA dan BRI serta menggunakan aplikasi internet banking. Jumlah sampel dalam penelitian ini ditentukan dengan menggunakan rumus sebagai berikut (Rao, 1996)

$$
n=\frac{Z^{2}}{4(M o e)^{2}}
$$

Keterangan:

$n \quad=$ ukuran sampel

$Z=1,96$ score pada tingkat signifikansi tertentu (derajat keyakinan ditentukan sebesar 95\%)

Moe $=$ Margin of Error, tingkat kesalahan maksimum adalah 10\%

Dengan menggunakan rumus di atas, maka diperoleh perhitungan sebagai berikut:

$$
\begin{gathered}
n=\frac{(1,96)^{2}}{4(10 \%)^{2}} \\
=96,04 \sim 97
\end{gathered}
$$

Berdasarkan perhitungan tersebut hasil yang didapatkan yaitu 97, untuk memudahkan dalam melakukan penelitian, maka ditetapkan sebagai sampel sebanyak 100 responden.

\section{Metode Pengumpulan Data}

Pada penelitian ini teknik yang digunakan dalam pengumpulan data, yakni dengan menggunakan kuesioner offline. Kuesioner tersebut kemudian disebarkan kepada 100 nasabah Bank Central Asia dan 100 nasabah Bank Rakyat Indonesia, dengan kriteria (1) Merupakan salah satu nasabah BCA dan BRI (2) Memiliki dan menggunakan aplikasi internet banking. Penyebaran Kuesioner dilakukan pada tanggal 8-11 Mei 2019 di area ATM Universitas Kristen Satya Wacana, di mana penyebaran kuesioner responden Bank Central Asia dilakukan pada tanggal 8-9 Mei 2019. Pada hari pertama penyebaran dilakukan sekitar pukul 11.00-15.30 dan mendapatkan 56 responden. Kemudian pada hari kedua berhasil mendapat seluruhnya yaitu 100 responden BCA yang dilakukan mulai pukul 10.00-14.00. Pada tanggal 10 dan 11 dilanjutkan penyebaran kuesioner responden BRI. Pada hari ketiga penyebaran 
dilakukan dari jam 11.30-14.00 dan mendapatkan 47 responden. Kemudian pada hari berikutnya dari jam 12.00-16.30 menyelesaikan kuesioner yang tersisa, sehingga mendapatkan 100 responden Bank Rakyat Indonesia.

Pengisian kuesioner oleh responden membutuhkan waktu sekitar 5-7 menit. Frekuensi rata-rata dalam 1 jam responden yang datang ke ATM adalah 14 orang dan beberapa responden yang datang bersama temannya membantu memberikan kuesioner ke temannya yang merupakan pengguna internet banking, sehingga proses penyebaran dapat selesai. Selama proses penyebaran dibantu oleh kedua teman, sehingga penyebaran kuesioner yang dilakukan lebih efektif. Penyebaran kuesioner dilakukan dengan cara mendatangi responden secara langsung setelah responden selesai melakukan transaksi di ATM, dan meminta mengisi kuesioner tersebut. Beberapa responden ada yang menolak untuk mengisi kuesioner dengan alasan tertentu. Setelah itu data dikumpulkan dan diuji terlebih dahulu guna memenuhi syarat kelengkapan data serta dianalisis menggunakan perangkat lunak SPSS 20. Penelitian ini menggunakan skala Likert lima tingkat dengan skor sangat tidak setuju $(\mathrm{STS})=5$, tidak setuju $(\mathrm{TS})=$ 4 , netral $(\mathrm{N})=3$, Setuju $(\mathrm{S})=2$, sangat setuju $(\mathrm{SS})=1$.

Tabel 2

\section{Definisi dan Pengukuran Variabel}

\begin{tabular}{|c|c|c|}
\hline Variabel & Definisi Variabel & Indikator \\
\hline Risiko Proses Internal & $\begin{array}{l}\text { Risiko Proses Internal didefinisikan } \\
\text { sebagai risiko yang berhubungan } \\
\text { dengan kegagalan proses dan prosedur } \\
\text { bank (Hardanto, 2006). }\end{array}$ & $\begin{array}{ll}\text { - } & \text { Kesalahan melakukan transaksi } \\
\text { - } & \text { Dokumentasi/arsip yang tidak lengkap } \\
\text { - } & \text { Kelalaian petugas pemasaran } \\
\text { - } & \text { Pengendalian intern yang lemah } \\
\text { - } & \text { Kesalahan dalam memberikan informasi } \\
\text { - } & \text { Laporan keuangan yang tidak lengkap atau tidak benar }\end{array}$ \\
\hline Risiko Manusia & $\begin{array}{l}\text { Risiko kesalahan manusia didefinisikan } \\
\text { sebagai risiko yang berhubungan } \\
\text { dengan karyawan bank. Kejadian risiko } \\
\text { operasional dapat dilakukan dengan } \\
\text { sengaja maupun tidak, dan tidak terbatas } \\
\text { pada unit tertentu (Hardanto, 2006). }\end{array}$ & 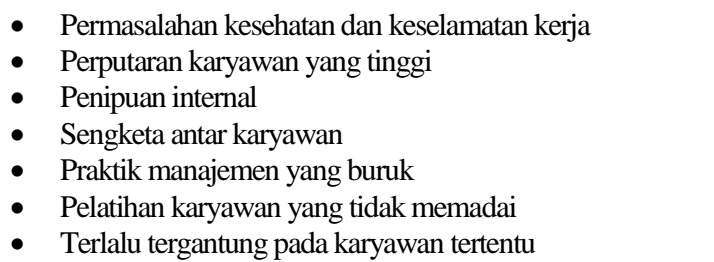 \\
\hline Risiko Sistem & $\begin{array}{l}\text { Risiko Sistem didefinisikan sebagai } \\
\text { risiko yang berhubungan dengan } \\
\text { penggunaan sistem dan teknologi } \\
\text { (Hardanto, 2006). }\end{array}$ & $\begin{array}{l}\text { - } \quad \text { Data yang tidak lengkap (data corruption) } \\
\text { - } \quad \text { Kesalahan input data (data entry errors) } \\
\text { - } \quad \text { Pengendalian perubahan data yang tidak memadai } \\
\text { - } \quad \text { Gangguan pelayanan,baik gangguan sebagian/ seluruhnya }\end{array}$ \\
\hline Risiko Eksternal & $\begin{array}{l}\text { Risiko Eksternal didefinisikan sebagai } \\
\text { risiko yang terjadi di luar kendali } \\
\text { organisasi, tetapi risiko eksternal jarang } \\
\text { terjadi di dalam organisasi. Tetapi jika } \\
\text { terjadi di sebuah organisasi risiko } \\
\text { eksternal membawa dampak yang } \\
\text { cukup besar } \\
\text { (Hardanto, 2006). }\end{array}$ & $\begin{array}{l}\text { - } \text { Pencurian dan penipuan dari luar } \\
\text { - } \text { Kebakaran } \\
\text { - } \text { Kencana lain } \\
\text { - } \quad \text { Penagalan perjanjian outsourcing ketentuan baru } \\
\text { - Kerusuhan dan unjuk rasa karyawan } \\
\text { - Kegagalan utility service (misal: listrik padam) }\end{array}$ \\
\hline Risiko Hukum & $\begin{array}{l}\text { Bank harus memastikan bahwa website } \\
\text { Bank menyediakan informasi yang } \\
\text { memungkinkan calon nasabah untuk } \\
\text { memperoleh informasi yang tepat me- } \\
\text { ngenai identitas dan status hukum Bank } \\
\text { sebelum melakukan transaksi melalui } \\
\text { internet banking (Hardanto, 2006). }\end{array}$ & $\begin{array}{l}\text { - } \quad \text { Penerapan ketentuan know-your-customer } \\
\text { - } \text { Kerahasiaan Bank } \\
\text { - } \quad \text { Penerapan ketentuan tentang perlindungan nasabah } \\
\text { - } \quad \text { Penerapan ketentuan perlindungan data }\end{array}$ \\
\hline
\end{tabular}

Sumber: Sunarjo dan Yuniarti, 2017

\section{Analisis Data dan Pembahasan Teknik Analisis Data}

Alat analisis yang digunakan dalam penelitian ini menggunakan alat analisis deskriptif kuantitatif. Pengolahan data dilakukan secara manual dan menggunakan komputer dengan program Microsoft Office Excel 
dan program SPSS. Kemudian melakukan uji validitas untuk mengetahui data yang di uji tersebut valid atau tidak valid dan melakukan uji reliabilitas menggunakan SPSS 20.

\section{Deskripsi Risiko Operasional Pada Bank Central Asia}

Data yang digunakan dalam penelitian ini diperoleh dari penyebaran kuesioner kepada para responden. Jumlah kuesioner yang disebar kepada para responden sebanyak 100 buah berdasarkan dengan jumlah sampel penelitian. Dari seluruh kuesioner yang telah disebar, data kemudian diolah dan dianalisis. Responden dalam penelitian ini adalah pengguna internet banking di BCA Salatiga.

\section{Karakteristik Responden}

Karakteristik responden pada Tabel 3 menunjukkan bahwa responden laki-laki 51\% lebih banyak dari responden wanita 49\%. Sebagian besar status para responden $99 \%$ belum menikah. Karakteristik responden berdasarkan penghasilan bulanan didominasi oleh responden yang berpenghasilan kurang dari 2.000.000 Rupiah sebanyak 57 responden atau (57\%). Dari data penggunaan internet banking dalam 1 bulan tersebut menunjukkan bahwa sebagian besar responden yang menggunakan internet banking per bulannya paling sering menggunakan dengan intensitas 1-3 kali sejumlah 45 orang (45\%), kemudian dengan intensitas 4-6 kali sejumlah 22 orang (22\%), dengan intensitas 7-10 kali sejumlah 12 orang (12\%), kemudian dengan intensitas lebih dari 10 kali sejumlah 21 orang (21\%), dan dengan intensitas tidak pernah menggunakan internet banking tiap bulannya tidak ada (0\%). Dari rentang usia, mayoritas responden berusia antara 20-25 tahun sebanyak 68 orang (68\%). Ini menunjukkan bahwa penggunaan internet banking didominasi oleh kaum muda. Dari latar belakang pendidikan, mayoritas responden adalah lulusan SMA. Dari data lama penggunaan internet banking tersebut menunjukkan bahwa sebagian besar responden menggunakan internet banking antara 1-2 tahun sejumlah 52 orang (52\%), kemudian responden yang menggunakan internet banking kurang dari 1 tahun sejumlah 17 orang (17\%), dan responden yang menggunakan internet banking antara 4-5 tahun sejumlah 12 orang (12\%), kemudian responden yang menggunakan internet banking lebih dari 5 tahun sejumlah 11 orang (11\%), dan responden yang menggunakan internet banking antara 3-4 tahun sejumlah 8 orang (8\%)

Tabel 3

Karakteristik Responden

\begin{tabular}{|c|c|c|c|}
\hline Kategori & Sub-Kategori & Jumlah Responden & Persentase (\%) \\
\hline \multirow[t]{2}{*}{ Jenis Kelamin } & Laki-laki & 51 & 51 \\
\hline & Perempuan & 49 & 49 \\
\hline \multirow[t]{2}{*}{ Status } & Menikah & 1 & 1 \\
\hline & Belum Menikah & 99 & 99 \\
\hline \multirow[t]{3}{*}{ Penghasilan } & $<2$ Juta & 57 & 57 \\
\hline & $2-5$ Juta & 39 & 39 \\
\hline & $>5$ Juta & 4 & 4 \\
\hline \multirow[t]{5}{*}{ Penggunaan Dalam 1 Bulan } & Tidak Pernah & 0 & 0 \\
\hline & $1-3$ kali & 45 & 45 \\
\hline & 4-6 kali & 22 & 22 \\
\hline & 7-10 kali & 12 & 12 \\
\hline & $>10$ kali & 21 & 21 \\
\hline \multirow[t]{4}{*}{ Usia } & $15-20$ & 27 & 27 \\
\hline & $20-25$ & 68 & 68 \\
\hline & $25-30$ & 4 & 4 \\
\hline & $30-35$ & 1 & 1 \\
\hline \multirow[t]{5}{*}{ Pendidikan Terakhir } & Tidak Tamat Sekolah Dasar & 0 & 0 \\
\hline & Sekolah Dasar (SD) & 0 & 0 \\
\hline & SMP/Sederajat & 2 & 2 \\
\hline & SMU/SMK/Sederajat & 66 & 66 \\
\hline & Akademi/Sarjana (D3/S1) & 32 & 32 \\
\hline \multirow[t]{5}{*}{ Lama Menggunakan } & $<1$ tahun & 17 & 17 \\
\hline & $1-2$ tahun & 52 & 52 \\
\hline & 3-4 tahun & 8 & 8 \\
\hline & 4-5 tahun & 12 & 12 \\
\hline & $>5$ tahun & 11 & 11 \\
\hline
\end{tabular}




\section{Uji Validitas dan Reliabilitas}

Menurut Sujarweni (2007), uji validitas digunakan untuk mengetahui kelayakan butir-butir dalam suatu daftar pertanyaan dalam mendefinisikan suatu variabel. Daftar pertanyaan ini pada umumnya mendukung suatu kelompok variabel tertentu. Uji validitas sebaiknya dilakukan pada setiap butir pertanyaan di uji validitasnya. Hasil $r$-hitung dibandingkan dengan $r$-tabel dengan $d f=n-2$ dengan sig. 5\%. Jika $r$-tabel $<r$-hitung, maka valid dan bernilai positif atau nilai $r$-hitung sig. < alpha 0,05 kemudian untuk $N=100$ dan $r$-tabelnya adalah 0,195 . Hasil uji menyatakan tingkat signifikansi seluruh variabel $0,00<0,05$, sehingga seluruh variabel dalam penelitian ini dapat dikatakan valid.

Menurut Sujarweni (2007), reliabilitas (keandalan) merupakan ukuran suatu kestabilan dan konsistensi responden dalam menjawab hal yang berkaitan dengan konstruk-konstruk pertanyaan yang merupakan dimensi suatu variabel dan disusun dalam suatu bentuk kuesioner. Uji reliabilitas dapat dilakukan secara bersama-sama terhadap seluruh butir pertanyaan. Jika Alpha >0,60, maka reliabel. Dapat dilihat pada Tabel 4, nilai Cronbach's Alpha dari keseluruhan variabel melebihi 0,60, sehingga data dapat dipercaya sebagai alat ukur variabel.

Tabel 4

Hasil Uji Reliabilitas

\begin{tabular}{cccc}
\hline Variabel & Cronbach's Alpha & Standar Reliabilitas & Keterangan \\
\hline Risiko Proses Internal & 0,826 & 0,60 & Reliabel \\
Risiko Manusia & 0,651 & 0,60 & Reliabel \\
Risiko Sistem & 0,627 & 0,60 & Reliabel \\
Risiko Eksternal & 0,650 & 0,60 & Reliabel \\
Risiko Hukum & 0,669 & 0,60 & Reliabel \\
\hline
\end{tabular}

Berdasarkan hasil uji tes reliabilitas dari data yang sudah diperoleh, dapat dilihat bahwa variabel Risiko Proses Internal diperoleh nilai Cronbach's Alpha sebesar 0,826, sehingga nilai pada variabel ini reliabel. Kemudian variabel Risiko Manusia diperoleh nilai Cronbach's Alpha sebesar 0,651, maka reliabel, kemudian variabel Risiko Sistem diperoleh nilai Cronbach's Alpha sebesar 0,627, maka reliabel, kemudian variabel Risiko Eksternal diperoleh nilai Cronbach's Alpha sebesar 0,650, dan Untuk variabel Risiko Hukum diperoleh nilai Cronbach's Alpha sebesar 0,672, maka reliabel.

\section{Deskripsi Variabel Penelitian}

Untuk menunjukkan rentang skala Likert dari rata-rata jawaban responden dengan keempat variabel pada penelitian ini, maka dapat diperoleh rumus:

$\begin{array}{ll}\text { Range } & \text { Keterangan } \\ 4,20-5,00 & \text { Sangat Tidak Setuju } \\ 3,40-4,19 & \text { Tidak Setuju } \\ 2,60-3,39 & \text { Netral } \\ 1,80-2,59 & \text { Setuju } \\ 1,00-1,79 & \text { Sangat Setuju }\end{array}$

$$
\text { Interval : } \frac{(\text { nilai max }- \text { nilai min })}{\text { jumlah kelas }}=\frac{(5-1)}{5}=0,8
$$

Kategori dari setiap variabel ditentukan dengan cara melihat dari nilai rata-rata tiap variabel tersebut. Berikut ini adalah Tabel deskripsi untuk menjelaskan variabel yang ada dalam penelitian ini. Data statistik deskriptif dari Tabel 5 deskripsi risiko proses internal pada Bank Central Asia menunjukkan keseluruhan indikator memiliki nilai rata-rata yang terletak antara range 3,40-4,19 yang berarti responden dari Bank Central Asia tidak setuju jika risiko proses internal pada internet banking berisiko untuk digunakan. Hal ini dengan kata lain, menunjukkan bahwa responden BCA menganggap internet banking relatif aman.

Data statistik deskriptif pada Tabel 6 menunjukkan rata-rata keseluruhan item dari variabel risiko manusia pada Bank Central Asia terletak antara range 3,40-4,19 yang berarti ratarata responden pada Bank Central Asia sama-sama tidak setuju jika risiko manusia pada internet banking berisiko untuk digunakan. 
Tabel 5

Deskripsi Risiko Proses Internal BCA

\begin{tabular}{lcc}
\hline Risiko Proses Internal & Rata-Rata & Kategori \\
\hline Kesalahan dalam transaksi & 3,82 & Tidak Setuju \\
Dokumentasi tidak lengkap & 3,87 & Tidak Setuju \\
Kelalaian petugas pemasaran & 3,89 & Tidak Setuju \\
Pengendalian yang lemah & 4,09 & Tidak Setuju \\
Kesalahan pemberian informasi & 4,04 & Tidak Setuju \\
Laporan keuangan yang tidak lengkap & 4,14 & Tidak Setuju \\
\hline
\end{tabular}

Pada indikator kedua dan ketiga menunjukkan rata-rata responden termasuk dalam kategori netral, sebagian responden netral terhadap perputaran karyawan yang tinggi dan penipuan internal. Hal ini menarik karena terdapat indikasi bahwa responden kurang mengetahui atau tidak yakin terhadap tidak adanya perputaran karyawan yang tinggi dan penipuan internal.

Tabel 6

Deskripsi Risiko Manusia

\begin{tabular}{lcc}
\hline Risiko Manusia & Rata-Rata & Kategori \\
\hline Masalah kesehatan dan keselamatan kerja & 3,51 & Tidak Setuju \\
Perputaran karyawan yang tinggi & 3,14 & Netral \\
Penipuan internal & 3,25 & Netral \\
Sengketa antar karyawan & 3,44 & Tidak Setuju \\
Praktik manajemen buruk & 4,05 & Tidak Setuju \\
Pelatihan yang tidak memadai & 3,85 & Tidak Setuju \\
Tergantung pada karyawan tertentu & 4,1 & Tidak Setuju \\
\hline
\end{tabular}

Data statistik deskriptif Tabel 7 risiko sistem menunjukkan pada keseluruhan indikator memiliki nilai rata-rata yang terletak antara range 3,40-4,19 yang berarti responden dari Bank Central Asia tidak setuju jika risiko manusia pada internet banking berisiko untuk digunakan. sedangkan pada indikator keempat menunjukkan sebagian responden termasuk dalam kategori netral. Sebagian responden netral terhadap gangguan layanan internet banking. Hal ini menarik karena terdapat indikasi bahwa responden kurang mengetahui atau tidak yakin terhadap tidak adanya gangguan layanan internet banking, baik gangguan secara keseluruhan maupun gangguan secara parsial.

Tabel 7

Deskripsi Risiko Sistem

\begin{tabular}{lcc}
\hline Risiko Sistem & Rata-Rata & Kategori \\
\hline Data yang tidak lengkap & 3,82 & Tidak Setuju \\
Kesalahan input data & 3,75 & Tidak Setuju \\
Pengendalian yang tidak memadai & 3,8 & Tidak Setuju \\
Gangguan pelayanan & 3,37 & Netral \\
\hline
\end{tabular}

Data statistik deskriptif pada Tabel 8 menunjukkan rata-rata keseluruhan item dari variabel risiko eksternal pada Bank Central Asia terletak antara range 3,40-4,19 yang berarti rata-rata responden pada Bank Central Asia sama-sama tidak setuju jika risiko eksternal pada internet banking berisiko untuk digunakan. sedangkan pada indikator keempat menunjukkan sebagian responden termasuk dalam kategori netral, sebagian responden netral terhadap adanya kegagalan perjanjian outsourcing. Hal ini menjadi perhatian karena terdapat indikasi bahwa responden kurang mengetahui tentang adanya kegagalan perjanjian outsourcing. 


\section{Tabel 8}

Deskripsi Risiko Eksternal

\begin{tabular}{lcc}
\hline Risiko Eksternal & Rata-Rata & Kategori \\
\hline Penipuan dari luar & 3,5 & Tidak Setuju \\
Kebakaran & 3,79 & Tidak Setuju \\
Bencana Lain & 3,71 & Tidak Setuju \\
Kegagalan perjanjian outsourcing & 3,38 & Netral \\
Penerapan ketentuan baru & 3,62 & Tidak Setuju \\
Kerusuhan/unjuk rasa karyawan & 3,55 & Tidak Setuju \\
Kegagalan utility & 3,75 & Tidak Setuju \\
\hline
\end{tabular}

Deskripsi Risiko Operasional pada Bank Rakyat Indonesia

Deskripsi risiko operasional dalam penelitian ini adalah pengguna internet banking di Bank Rakyat Indonesia Salatiga.

\section{Karakteristik Responden}

Karakteristik responden pada Tabel 10 menunjukkan bahwa responden wanita 56\% lebih banyak dari responden laki-laki 44\%. Sebagian besar status para responden $99 \%$ belum menikah. Karakteristik responden berdasarkan penghasilan bulanan didominasi oleh responden yang berpenghasilan kurang dari 2.000 .000 sebanyak 61 responden atau $(61 \%)$.

\section{Tabel 10}

\section{Karakteristik Responden}

\begin{tabular}{cccc}
\hline Kategori & Sub-Kategori & Jumlah Responden & Persentase (\%) \\
\hline \multirow{2}{*}{ Jenis Kelamin } & Pria & 44 & 44 \\
Status & Wanita & 56 & 56 \\
& Menikah & 1 & 1 \\
& Belum Menikah & 99 & 99 \\
& < 2 Juta & 61 & 61 \\
2-5 Juta & 37 & 37 \\
Penghasilan & > 5 Juta & 2 & 2 \\
& $1-3$ kali & 71 & 71 \\
& 4-6 kali & 13 & 13 \\
& 7-10 kali & 9 & 9 \\
& $>10$ kali & 7 & 7 \\
Usia & $15-20$ & 20 & 20 \\
& 20-25 & 79 & 79 \\
& 25-30 & 1 & 1 \\
Pendidikan & 30-35 & 0 & 0 \\
Terakhir & Tidak Tamat SD & 0 & 0 \\
& Sekolah Dasar (SD) & 0 & 0 \\
& SMP/Sederajat & 0 & 0 \\
Lama & SMU/SMK/Sederajat & 63 & 63 \\
Menggunakan & Akademi/Sarjana & 37 & 37 \\
& < 1 tahun & 25 & 25 \\
& 1-2 tahun & 39 & 39 \\
& 3-4 tahun & 17 & 17 \\
& 4-5 tahun & 11 & 11 \\
\hline
\end{tabular}

Dari data penggunaan internet banking dalam satu bulan tersebut menunjukkan bahwa sebagian besar responden yang menggunakan internet banking per bulannya paling sering menggunakan dengan intensitas 1-3 kali sejumlah 71 orang (71\%), kemudian dengan intensitas 4-6 kali sejumlah 13 orang (13\%), dengan intensitas 7-10 kali sejumlah sembilan orang (9\%), kemudian dengan intensitas 
lebih dari 10 kali sejumlah tujuh orang (7\%), dan dengan intensitas tidak pernah menggunakan internet banking tiap bulannya tidak ada $(0 \%)$.

Dari rentang usia, mayoritas responden berusia antara 20-25 tahun sebanyak 79 orang (79\%). Ini menunjukkan bahwa penggunaan internet banking didominasi oleh kaum muda. Dari latar belakang pendidikan, mayoritas responden adalah lulusan SMA sebanyak 63 orang (63\%).

Dari data lama penggunaan internet banking tersebut menunjukkan bahwa sebagian besar responden menggunakan internet banking antara 1-2 tahun sejumlah 39 orang (39\%), kemudian responden yang menggunakan internet banking kurang dari satu tahun sejumlah 25 orang (25\%), dan responden yang menggunakan internet banking antara 4-5 tahun sejumlah 11 orang (11\%), kemudian responden yang menggunakan internet banking lebih dari lima tahun sejumlah delapan orang (8\%), dan responden yang menggunakan internet banking antara 3-4 tahun sejumlah 17 orang (17\%).

\section{Uji Validitas dan Reliabilitas}

Hasil uji validitas pada Bank Rakyat Indonesia menyatakan tingkat signifikansi seluruh variabel $0,00<$ 0,05 , sehingga seluruh variabel dalam penelitian ini dapat dikatakan valid. Uji reliabilitas pada Bank Rakyat Indonesia dapat dilakukan secara bersama-sama terhadap seluruh butir pertanyaan. Jika Alpha >0,060, maka reliabel. Dapat dilihat pada Tabel 11, nilai Cronbach's Alpha dari keseluruhan variabel melebihi 0,60, sehingga data dapat dipercaya sebagai alat ukur variabel.

Tabel 11

Hasil Uji Reliabilitas

\begin{tabular}{cccc}
\hline Variabel & Cronbach's Alpha & Standar Reliabilitas & Keterangan \\
\hline Risiko Proses Internal & 0,880 & 0,60 & Reliabel \\
Risiko Manusia & 0,810 & 0,60 & Reliabel \\
Risiko Sistem & 0,639 & 0,60 & Reliabel \\
Risiko Eksternal & 0,626 & 0,60 & Reliabel \\
Risiko Hukum & 0,619 & 0,60 & Reliabel \\
\hline
\end{tabular}

Berdasarkan hasil uji tes reliabilitas dari data yang sudah diperoleh, dapat dilihat bahwa variabel Risiko Proses Internal diperoleh nilai Cronbach's Alpha sebesar 0,880, sehingga nilai pada variabel ini reliabel. Kemudian variabel Risiko Manusia diperoleh nilai Cronbach's Alpha sebesar 0,810, maka reliabel, kemudian variabel Risiko Sistem diperoleh nilai Cronbach's Alpha sebesar 0,639, maka reliabel, kemudian variabel Risiko Eksternal diperoleh nilai Cronbach's Alpha sebesar 0,626, dan Untuk variabel Risiko Hukum diperoleh nilai Cronbach's Alpha sebesar 0,619, maka reliabel.

\section{Deskripsi Variabel Penelitian}

Dari Tabel 12 risiko proses internal pada keseluruhan indikator memiliki nilai rata-rata yang terletak antara range 3,40-4,19 yang berarti responden dari Bank Rakyat Indonesia tidak setuju jika risiko proses internal pada internet banking berisiko untuk digunakan. Hal ini dengan kata lain, menunjukkan bahwa responden BRI menganggap internet banking relatif aman.

\section{Tabel 12}

Deskripsi Risiko Proses Internal

\begin{tabular}{lcc}
\hline Risiko Proses Internal & Rata-Rata & Kategori \\
\hline Kesalahan dalam transaksi & 3,51 & Tidak Setuju \\
Dokumentasi tidak lengkap & 3,79 & Tidak Setuju \\
Kelalaian petugas pemasaran & 3,63 & Tidak Setuju \\
Pengendalian yang lemah & 3,75 & Tidak Setuju \\
Kesalahan pemberian informasi & 3,76 & Tidak Setuju \\
Laporan keuangan yang tidak lengkap & 3,74 & Tidak Setuju \\
\hline
\end{tabular}

Data statistik deskriptif pada Tabel 13 menunjukkan rata-rata keseluruhan item dari variabel risiko manusia pada Bank Rakyat Indonesia terletak antara range 3,40-4,19 yang berarti rata-rata responden pada Bank Rakyat Indonesia sama-sama tidak setuju jika risiko manusia pada internet banking berisiko untuk digunakan. Pada indikator kedua dan keempat menunjukkan rata-rata responden termasuk dalam kategori netral, sebagian responden netral terhadap perputaran karyawan yang tinggi dan sengketa antar karyawan. Hal ini menarik 
karena terdapat indikasi bahwa responden kurang mengetahui atau tidak yakin terhadap tidak adanya perputaran karyawan yang tinggi dan sengketa antar karyawan.

Tabel 13

Deskripsi Risiko Manusia

\begin{tabular}{lcc}
\hline Risiko Manusia & Rata-rata & Kategori \\
\hline Masalah kesehatan dan keselamatan kerja & 3,45 & Tidak Setuju \\
Perputaran karyawan yang tinggi & 3,32 & Netral \\
Penipuan internal & 3,44 & Tidak Setuju \\
Sengketa antar karyawan & 3,34 & Netral \\
Praktik manajemen buruk & 3,69 & Tidak Setuju \\
Pelatihan yang tidak memadai & 3,59 & Tidak Setuju \\
Tergantung pada karyawan tertentu & 3,69 & Tidak Setuju \\
\hline
\end{tabular}

Data statistik deskriptif Tabel 14 risiko sistem menunjukkan pada keseluruhan indikator memiliki nilai rata-rata yang terletak antara range 3,40-4,19 yang berarti responden dari Bank Rakyat Indonesia tidak setuju jika risiko manusia pada internet banking berisiko untuk digunakan. Hal ini dengan kata lain, menunjukkan bahwa responden BRI menganggap internet banking relatif aman dari segi risiko sistem.

\section{Tabel 14}

Deskripsi Risiko Sistem

\begin{tabular}{lcc}
\hline Risiko Sistem & Rata-rata & Kategori \\
\hline Data yang tidak lengkap & 3,58 & Tidak Setuju \\
Kesalahan input data & 3,61 & Tidak Setuju \\
Pengendalian yang tidak memadai & 3,65 & Tidak Setuju \\
Gangguan pelayanan & 3,61 & Tidak Setuju \\
\hline
\end{tabular}

Data statistik deskriptif menunjukkan pada Tabel 15, rata-rata keseluruhan item dari variabel risiko eksternal pada Bank Rakyat Indonesia terletak antara range 3,40-4,19 yang berarti rata-rata responden pada Bank Rakyat Indonesia sama-sama tidak setuju jika risiko eksternal pada internet banking berisiko untuk digunakan. sedangkan pada indikator kesatu menunjukkan sebagian responden termasuk dalam kategori netral. Responden dalam melakukan transaksi internet banking, tidak merasa terlindungi dari penipuan dari luar memiliki jawaban netral.

\section{Tabel 15}

Deskripsi Risiko Eksternal

\begin{tabular}{lcc}
\hline Risiko Eksternal & Rata-Rata & Kategori \\
\hline Penipuan dari luar & 3,31 & Netral \\
Kebakaran & 3,81 & Tidak Setuju \\
Bencana Lain & 3,85 & Tidak Setuju \\
Kegagalan perjanjian outsourcing & 3,6 & Tidak Setuju \\
Penerapan ketentuan baru & 3,73 & Tidak Setuju \\
Kerusuhan/unjuk rasa karyawan & 3,66 & Tidak Setuju \\
Kegagalan utility & 4,02 & Tidak Setuju \\
\hline
\end{tabular}

\section{Tabel 16}

Deskripsi Risiko Hukum

\begin{tabular}{lcl}
\hline Risiko Hukum & Rata-rata & Kategori \\
\hline Penerapan ketentuan know-your-customer & 3,43 & Tidak Setuju \\
Kerahasiaan Bank & 3,89 & Tidak Setuju \\
Penerapan ketentuan data & 3,84 & Tidak Setuju \\
\hline
\end{tabular}

Data statistik deskriptif pada Tabel 16 menunjukkan rata-rata keseluruhan item dari variabel risiko hukum pada Bank Rakyat Indonesia terletak antara range 3,40-4,19 yang berarti rata-rata responden pada Bank Rakyat Indonesia sama-sama tidak setuju jika risiko hukum pada internet banking berisiko untuk digunakan Hal ini 
dengan kata lain, menunjukkan bahwa responden BRI menganggap internet banking relatif aman dari segi risiko hukum.

\section{Perbedaan Risiko Operasional Digital Banking Pada Bank Central Asia dan Bank Rakyat Indonesia}

Pada Tabel 17 dapat dilihat pada risiko manusia nasabah BCA lebih skeptis terhadap penipuan internal dibandingkan nasabah BRI, dan nasabah BRI lebih skeptis terhadap terjadinya sengketa antar karyawan dibandingkan dengan nasabah BCA. Untuk risiko sistem nasabah BCA lebih skeptis terhadap gangguan pelayanan dibandingkan dengan nasabah BRI. Untuk risiko eksternal dapat dilihat BRI lebih skeptis terhadap penipuan dari luar dibandingkan dengan nasabah BCA, dan nasabah BCA lebih skeptis terhadap kegagalan perjanjian outsourcing dibandingkan dengan nasabah BRI. Bagi BCA kemungkinan perlu melihat masalah penipuan internal, gangguan pelayanan, dan kegagalan perjanjian outsourcing, sedangkan untuk BRI perlu melihat sengketa antar karyawan dan penipuan dari luar.

Tabel 17

DeskripsiPerbedaan BCA dan BRI

\begin{tabular}{lcccc}
\hline \multirow{2}{*}{ Indikator } & \multicolumn{2}{c}{ Rata-Rata } & \multicolumn{2}{c}{ Kategori } \\
\cline { 2 - 5 } & BCA & BRI & BCA & BRI \\
\hline Risiko Manusia & 3,25 & 3,44 & Netral & Tidak Setuju \\
$\begin{array}{l}\text { Penipuan internal } \\
\text { Sengketa antar karyawan }\end{array}$ & 3,44 & 3,34 & Tidak setuju & Netral \\
Risiko Sistem & & & & Tidak Setuju \\
Gangguan pelayanan & 3,37 & 3,61 & Netral & Netral \\
Risiko Eksternal & & & Tidak Setuju & Netral \\
$\begin{array}{l}\text { Penipuan dari luar } \\
\text { Kegagalan perjanjian outsourching }\end{array}$ & 3,50 & 3,38 & 3,60 & Tidak Setuju \\
\hline
\end{tabular}

Pada Tabel 18 menunjukkan deskripsi variabel risiko proses internal, risiko manusia, risiko sistem, risiko eksternal, persepsi risiko, dan risiko hukum dibahas pada bagian berikut analisis statistik deskriptif baik pada variabel keseluruhan dan untuk setiap indikator dari variabel yang diteliti berdasarkan pada nilai minimum, nilai maksimum, rata-rata, dan standar deviasi.

Data statistik deskriptif pada Tabel 18 menunjukkan rata-rata atau rata-rata keseluruhan item dari variabel risiko proses internal BCA adalah 3,97 terletak antara range 3,40-4,19 sedangkan BRI adalah 3,69 yang berarti rata-rata responden pada BCA dan BRI sama-sama tidak setuju jika risiko proses internal pada internet banking berisiko untuk digunakan. Dapat dilihat juga perbedaan antara kedua bank tersebut. BCA memiliki rata-rata lebih besar daripada BRI, maka dapat dikatakan bahwa BCA lebih dipercaya dari BRI karena memiliki skor skor lebih tinggi.

Variabel risiko manusia pada BCA memiliki nilai rata-rata 3,62 dan BRI 3,50, keduanya terletak pada range 3,40-4,19 yang berarti responden dari kedua bank tersebut tidak setuju jika risiko manusia pada internet banking berisiko untuk digunakan. Dari keenam indikator tersebut pada variabel risiko manusia, BCA memiliki skor lebih tinggi dari BRI, namun ada beberapa item yang menunjukkan BRI lebih tinggi seperti pada indikator kedua dan ketiga BCA memiliki efek negatif.

Variabel risiko sistem pada Bank Central Asia memiliki nilai rata-rata 3,68 dan Bank Rakyat Indonesia 3,61, keduanya terletak pada range 3,40-4,19 yang berarti responden dari kedua bank tersebut tidak setuju jika risiko sistem pada internet banking berisiko untuk digunakan. Sebagian besar BCA memiliki skor lebih tinggi dan memiliki efek positif pada risiko sistem, namun pada indikator keempat BCA memiliki skor yang lebih rendah dan memiliki efek negatif. Pada aspek gangguan pelayanan BCA lebih sering mengalami gangguan pelayanan dari BRI. Hal ini diduga berkaitan dengan kepemilikan satelit oleh BRI yang memungkinkan diminimalkannya gangguan pelayanan di BRI.

Variabel risiko eksternal pada Bank Central Asia memiliki nilai rata-rata 3,61 dan Bank Rakyat Indonesia 3,71, keduanya terletak pada range 3,40-4,19 yang berarti responden dari kedua bank tersebut tidak setuju jika risiko eksternal pada internet banking berisiko untuk digunakan. Dari kedua bank pada indikator ketujuh dalam variabel risiko eksternal, indikator nomor 7 pada Bank Rakyat Indonesia memiliki nilai rata-rata tertinggi yaitu 4,02. Itu menunjukkan bahwa beberapa responden dari Bank Rakyat Indonesia tidak setuju jika Bank tidak dapat mengatasi kegagalan utility service (misal: jaring- 
an satelit error). Pada indikator risiko eksternal sebagian besar BCA memiliki skor rendah dan memiliki efek negatif dan BRI memiliki skor tertinggi hampir di semua aspek dan memiliki efek positif. Keunggulan BRI dalah hal kepemilikan satelit tersebut menyebabkan rendahnya risiko eksternal yang dipersepsi nasabah bank tersebut dibandingkan persepsi nsabah BCA.

Variabel risiko hukum pada Bank Central Asia memiliki nilai rata-rata 3,77 dan Bank Rakyat Indonesia 3,72, keduanya terletak pada range 3,40-4,19 yang berarti responden dari kedua bank tersebut tidak setuju jika risiko hukum pada internet banking berisiko untuk digunakan. Dapat dilihat juga perbedaan antara kedua bank tersebut. Bank Central Asia memiliki rata-rata lebih besar dan memiliki efek positif pada semua aspek risiko hukum daripada Bank Rakyat Indonesia, maka dapat dikatakan bahwa Bank Central Asia lebih baik dan lebih dipercaya daripada Bank Rakyat Indonesia. Hasil ini menunjukkan bahwa kemampuan BCA mengelola risiko hukum yang banyak terkait dengan implementasi tata kelola mendapatkan pengakuan dari nasabah bank tersebut, sehingga dinilai lebih unggul bila dibandingkan dengan BRI. Hal ini diduga tidak dapat dilepaskan dari profesionalisme pengelolaan bank swasta dibandingkan bank pemerintah seperti BRI.

Tabel 18

Statistik Deskriptif Variabel Penelitian BCA dan BRI

\begin{tabular}{|c|c|c|c|c|c|c|c|c|c|}
\hline \multirow[b]{2}{*}{ Indikator Empiris } & \multicolumn{4}{|c|}{ BCA } & \multicolumn{4}{|c|}{ BRI } & \multirow{2}{*}{$\begin{array}{l}\text { Mean BCA } \\
\text {-Mean BRI }\end{array}$} \\
\hline & Min & Max & Mean & $\begin{array}{l}\text { Std. } \\
\text { Dev. }\end{array}$ & Min & Max & Mean & $\begin{array}{l}\text { Std. } \\
\text { Dev. }\end{array}$ & \\
\hline \multicolumn{10}{|l|}{ Risiko Proses Internal } \\
\hline Kesalahan dalam transaksi & 2,00 & 5,00 & 3,82 & 0,99 & 1,00 & 5,00 & 3,51 & 1,21 & 0,31 \\
\hline Dokumentasi tidak lengkap & 1,00 & 5,00 & 3,87 & 0,93 & 2,00 & 5,00 & 3,79 & 0,94 & 0,08 \\
\hline Kelalaian petugas pemasaran & 2,00 & 5,00 & 3,89 & 0,83 & 2,00 & 5,00 & 3,63 & 0,97 & 0,26 \\
\hline Pengendalian yang lemah & 1,00 & 5,00 & 4,09 & 0,91 & 1,00 & 5,00 & 3,75 & 0,96 & 0,34 \\
\hline Kesalahan pemberian informasi & 1,00 & 5,00 & 4,04 & 1,00 & 1,00 & 5,00 & 3,76 & 0,98 & 0,28 \\
\hline Laporan keuangan yang tidak lengkap & 1,00 & 5,00 & 4,14 & 0,86 & 1,00 & 5,00 & 3,74 & 1,03 & 0,40 \\
\hline Rata-rata risiko proses internal & 1,33 & 5,00 & 3,97 & 0,92 & 1,33 & 5,00 & 3,69 & 1,01 & 0,28 \\
\hline \multicolumn{10}{|l|}{ Risiko Manusia } \\
\hline Masalah kesehatan dan keselamatan kerja & 1,00 & 5,00 & 3,51 & 0,97 & 1,00 & 5,00 & 3,45 & 1,01 & 0,06 \\
\hline Perputaran karyawan yang tinggi & 1,00 & 5,00 & 3,14 & 1,11 & 1,00 & 5,00 & 3,32 & 1,09 & $-0,18$ \\
\hline Penipuan internal & 1,00 & 5,00 & 3,25 & 1,07 & 1,00 & 5,00 & 3,44 & 1,08 & $-0,19$ \\
\hline Sengketa antar karyawan & 1,00 & 5,00 & 3,44 & 1,01 & 1,00 & 5,00 & 3,34 & 1,12 & 0,10 \\
\hline Praktek manajemen buruk & 2,00 & 5,00 & 4,05 & 0,74 & 1,00 & 5,00 & 3,69 & 0,86 & 0,36 \\
\hline Pelatihan yang tidak memadai & 2,00 & 5,00 & 3,85 & 0,78 & 1,00 & 5,00 & 3,59 & 0,88 & 0,26 \\
\hline Tergantung pada karyawan tertentu & 2,00 & 5,00 & 4,10 & 0,81 & 2,00 & 5,00 & 3,69 & 1,01 & 0,41 \\
\hline Rata-rata risiko manusia & 1,42 & 5,00 & 3,62 & 0,92 & 1,14 & 5,00 & 3,50 & 1,00 & 0,12 \\
\hline \multicolumn{10}{|l|}{ Risiko Sistem } \\
\hline Data yang tidak lengkap & 1,00 & 5,00 & 3,82 & 0,86 & 1,00 & 5,00 & 3,58 & 0,90 & 0,24 \\
\hline Kesalahan input data & 1,00 & 5,00 & 3,75 & 0,88 & 1,00 & 5,00 & 3,61 & 0,94 & 0,14 \\
\hline Pengendalian yang tidak memadai & 1,00 & 5,00 & 3,80 & 0,77 & 2,00 & 5,00 & 3,65 & 0,78 & 0,15 \\
\hline Gangguan pelayanan & 1,00 & 5,00 & 3,37 & 1,05 & 1,00 & 5,00 & 3,61 & 0,89 & $-0,24$ \\
\hline Rata-rata risiko sistem & 1,00 & 5,00 & 3,68 & 0,89 & 1,25 & 5,00 & 3,61 & 0,87 & 0,07 \\
\hline \multicolumn{10}{|l|}{ Risiko Eksternal } \\
\hline Penipuan dari luar & 1,00 & 5,00 & 3,50 & 1,06 & 1,00 & 5,00 & 3,31 & 1,01 & 0,19 \\
\hline Kebakaran & 1,00 & 5,00 & 3,79 & 0,92 & 2,00 & 5,00 & 3,81 & 0,81 & $-0,02$ \\
\hline Bencana Lain & 1,00 & 5,00 & 3,71 & 1,02 & 1,00 & 5,00 & 3,85 & 0,88 & $-0,14$ \\
\hline Kegagalan perjanjian outsourcing & 1,00 & 5,00 & 3,38 & 0,94 & 1,00 & 5,00 & 3,60 & 0,96 & $-0,22$ \\
\hline Penerapan ketentuan baru & 1,00 & 5,00 & 3,62 & 0,92 & 1,00 & 5,00 & 3,73 & 0,88 & $-0,11$ \\
\hline Kerusuhan/unjuk rasa karyawan & 1,00 & 5,00 & 3,55 & 0,93 & 1,00 & 5,00 & 3,66 & 0,94 & $-0,11$ \\
\hline Kegagalan utility & 1,00 & 5,00 & 3,75 & 0,98 & 2,00 & 5,00 & 4,02 & 0,81 & $-0,27$ \\
\hline Rata-rata risiko eksternal & 1,00 & 5,00 & 3,61 & 0,96 & 1,28 & 5,00 & 3,71 & 0,89 & $-0,10$ \\
\hline \multicolumn{10}{|l|}{ Risiko Hukum } \\
\hline $\begin{array}{l}\text { Penerapan ketentuan know-your- } \\
\text { customer }\end{array}$ & 1,00 & 5,00 & 3,54 & 0,92 & 1,00 & 5,00 & 3,43 & 0,89 & 0,11 \\
\hline Kerahasiaan Bank & 1,00 & 5,00 & 3,89 & 0,90 & 1,00 & 5,00 & 3,89 & 0,88 & 0 \\
\hline Penerapan ketentuan data & 1,00 & 5,00 & 3,90 & 0,87 & 1,00 & 5,00 & 3,84 & 0,92 & 0,05 \\
\hline Rata-rata risiko hukum & 1,00 & 5,00 & 3,77 & 0,89 & 1,00 & 5,00 & 3,72 & 0,89 & 0,05 \\
\hline Rata-rata Keseluruhan & 1,18 & 5,00 & 3,72 & 0,92 & 1,20 & 5,00 & 3,64 & 0,94 & 0,08 \\
\hline
\end{tabular}




\section{Uji Crosstab Nasabah BCA}

Berdasarkan hasil uji crosstab gender nasabah BCA pada Tabel 19 menunjukkan bahwa terdapat kesamaan persepsi risiko di kalangan laki-laki dan perempuan untuk risiko proses internal (RPI), risiko sistem (RS) dan risiko eksternal (RE), hasil yang berkebalikan ditemukan untuk risiko manusia $(\mathrm{RM})$ dan risiko hukum $(\mathrm{RH})$. Laki-laki cenderung menganggap kedua risiko tersebut lebih tinggi dibandingkan perempuan.

Tabel 19

Hasil Uji Crosstab Gender Nasabah BCA

\begin{tabular}{ccccccccccc}
\hline \multirow{2}{*}{ Gender } & \multicolumn{2}{c}{ RPI } & \multicolumn{2}{c}{ RM } & \multicolumn{2}{c}{ RS } & \multicolumn{2}{c}{ RE } & \multicolumn{2}{c}{ RH } \\
\cline { 2 - 11 } & Rendah & Tinggi & Rendah & Tinggi & Rendah & Tinggi & Rendah & Tinggi & Rendah & Tinggi \\
\hline Laki-laki & 22 & 29 & 23 & 28 & 21 & 30 & 30 & 21 & 20 & 31 \\
$\%$ & $43,1 \%$ & $56,9 \%$ & $45,1 \%$ & $54,9 \%$ & $41,2 \%$ & $58,8 \%$ & $58,8 \%$ & $41,2 \%$ & $39,2 \%$ & $60,8 \%$ \\
Perempuan & 18 & 31 & 26 & 23 & 23 & 26 & 25 & 24 & 28 & 21 \\
$\%$ & $36,7 \%$ & $63,3 \%$ & $53,1 \%$ & $46,9 \%$ & $46,9 \%$ & $53,1 \%$ & $51,0 \%$ & $49,0 \%$ & $57,1 \%$ & $42,9 \%$ \\
\hline
\end{tabular}

Berdasarkan hasil uji crosstab status pernikahan nasabah BCA pada Tabel 20 menunjukkan bahwa terdapat kesamaan persepsi risiko di kalangan nasabah yang belum menikah dan yang sudah menikah untuk sebagian besar risiko memiliki kesamaan, namun pada risiko hukum (RH) terdapat perbedaan. Nasabah yang belum menikah cenderung menganggap risiko tersebut lebih tinggi dibandingkan yang sudah menikah.

Tabel 20

Hasil Uji Crosstab Status Nasabah BCA

\begin{tabular}{cccccccccccc}
\hline \multirow{2}{*}{ Status } & \multicolumn{2}{c}{ RPI } & \multicolumn{2}{c}{ RM } & \multicolumn{2}{c}{ RS } & \multicolumn{2}{c}{ RE } & \multicolumn{2}{c}{ RH } \\
\cline { 2 - 10 } & Rendah & Tinggi & Rendah & Tinggi & Rendah & Tinggi & Rendah & Tinggi & Rendah & Tinggi \\
\hline Menikah & 0 & 1 & 0 & 1 & 0 & 1 & 1 & 0 & 1 & 0 \\
$\%$ & $0,0 \%$ & $100,0 \%$ & $0,0 \%$ & $100,0 \%$ & $0,0 \%$ & $100,0 \%$ & $100,0 \%$ & $0,0 \%$ & $100,0 \%$ & $0,0 \%$ \\
Belum Menikah & 40 & 59 & 49 & 50 & 44 & 55 & 54 & 45 & 47 & 52 & $52,5 \%$ \\
$\%$ & $40,4 \%$ & $59,6 \%$ & $49,5 \%$ & $50,5 \%$ & $44,4 \%$ & $55,6 \%$ & $54,5 \%$ & $45,5 \%$ & $47,5 \%$ & $52,5 \%$ \\
\hline
\end{tabular}

Berdasarkan hasil uji crosstab penghasilan nasabah BCA pada Tabel 21 menunjukkan bahwa terdapat kesamaan persepsi risiko di kalangan nasabah dengan penghasilan $<2$ juta untuk risiko proses internal (RPI), untuk risiko manusia (RM), risiko sistem (RS) dan risiko hukum (RH), hasil yang berkebalikan ditemukan pada risiko eksternal (RE). Nasabah berpenghasilan 2-5 juta cenderung menganggap risiko tersebut lebih tinggi.

Tabel 91

Hasil Uji Crosstab Penghasilan Nasabah BCA

\begin{tabular}{ccccccccccc}
\hline \multirow{2}{*}{ Penghasilan } & \multicolumn{2}{c}{ RPI } & \multicolumn{2}{c}{ RM } & \multicolumn{2}{c}{ RS } & \multicolumn{2}{c}{ RE } & \multicolumn{2}{c}{ RH } \\
\cline { 2 - 10 } & Rendah & Tinggi & Rendah & Tinggi & Rendah & Tinggi & Rendah & Tinggi & Rendah & Tinggi \\
\hline$<2$ juta & 23 & 34 & 28 & 29 & 26 & 31 & 38 & 19 & 27 & 30 \\
$\%$ & $40,4 \%$ & $59,6 \%$ & $49,1 \%$ & $50,9 \%$ & $45,6 \%$ & $54,4 \%$ & $66,7 \%$ & $33,3 \%$ & $47,4 \%$ & $52,6 \%$ \\
$2-5$ juta & 16 & 23 & 20 & 19 & 15 & 24 & 14 & 25 & 20 & 19 \\
$\%$ & $41,0 \%$ & $59,0 \%$ & $51,3 \%$ & $48,7 \%$ & $38,5 \%$ & $61,5 \%$ & $35,9 \%$ & $64,1 \%$ & $51,3 \%$ & $48,7 \%$ \\
$>5$ juta & 1 & 3 & 1 & 3 & 3 & 1 & 3 & 1 & 1 & 3 \\
$\%$ & $25,0 \%$ & $75,0 \%$ & $25,0 \%$ & $75,0 \%$ & $75,0 \%$ & $25,0 \%$ & $75,0 \%$ & $25,0 \%$ & $25,0 \%$ & $75,0 \%$ \\
\hline
\end{tabular}

Berdasarkan hasil uji crosstab penggunaan per bulan nasabah BCA pada Tabel 22 menunjukkan bahwa terdapat kesamaan persepsi risiko pada penggunaan 1-3 kali untuk risiko proses internal (RPI), untuk risiko manusia (RM), risiko sistem (RS) dan risiko hukum (RH), hasil yang berkebalikan ditemukan pada risiko eksternal (RE). Nasabah cenderung menganggap risiko tersebut lebih rendah. Pada 
penggunaan 4-6 kali terdapat kesamaan untuk risiko proses internal, risiko sistem dan risiko hukum, hasil yang berkebalikan ditemukan pada risiko manusia dan risiko eksternal. Untuk penggunaan 7-10 kali semuanya memiliki kesamaan, dan untuk penggunaan > 10 kali terdapat kesamaan pada risiko proses internal, risiko manusia, risiko sistem, dan risiko eksternal namun hasil yang berkebalikan pada risiko hukum.

Tabel 22

Hasil Uji Crosstab Penggunaan Per Bulan Nasabah BCA

\begin{tabular}{ccccccccccc}
\hline \multirow{2}{*}{ Penggunaan } & \multicolumn{2}{c}{ RPI } & \multicolumn{2}{c}{ RM } & \multicolumn{2}{c}{ RS } & \multicolumn{2}{c}{ RE } & RH \\
\cline { 2 - 10 } & Rendah & Tinggi & Rendah & Tinggi & Rendah & Tinggi & Rendah & Tinggi & Rendah & Tinggi \\
\hline $1-3$ kali & 22 & 23 & 21 & 24 & 19 & 26 & 28 & 17 & 24 & 21 \\
$\%$ & $48,9 \%$ & $51,1 \%$ & $46,7 \%$ & $53,3 \%$ & $42,2 \%$ & $57,8 \%$ & $62,2 \%$ & $37,8 \%$ & $53,3 \%$ & $46,7 \%$ \\
$4-6$ kali & 3 & 19 & 12 & 10 & 10 & 12 & 13 & 9 & 10 & 12 \\
$\%$ & $13,6 \%$ & $86,4 \%$ & $54,5 \%$ & $45,5 \%$ & $45,5 \%$ & $54,5 \%$ & $59,1 \%$ & $40,9 \%$ & $45,5 \%$ & $54,5 \%$ \\
$7-10$ kali & 4 & 8 & 5 & 7 & 4 & 8 & 3 & 9 & 5 & 7 \\
$\%$ & $33,3 \%$ & $66,7 \%$ & $41,7 \%$ & $58,3 \%$ & $33,3 \%$ & $66,7 \%$ & $25,0 \%$ & $75,0 \%$ & $41,7 \%$ & $58,3 \%$ \\
$>10$ kali & 11 & 10 & 11 & 10 & 11 & 10 & 11 & 10 & 9 & 12 \\
$\%$ & $52,4 \%$ & $47,6 \%$ & $52,4 \%$ & $47,6 \%$ & $52,4 \%$ & $47,6 \%$ & $52,4 \%$ & $47,6 \%$ & $42,9 \%$ & $57,1 \%$ \\
\hline
\end{tabular}

Berdasarkan hasil uji crosstab tingkat pendidikan nasabah BCA pada Tabel 23 menunjukkan bahwa terdapat kesamaan persepsi risiko pada tingkat pendidikan untuk risiko proses internal (RPI), untuk risiko manusia (RM), risiko sistem (RS) dan risiko eksternal (RE), hasil yang berkebalikan ditemukan pada risiko hukum (RH). Nasabah dengan tingkat pendidikan SMU dan S1 cenderung menganggap risiko tersebut lebih tinggi.

Tabel 23

Hasil Uji Crosstab Tingkat Pendidikan Nasabah BCA

\begin{tabular}{ccccccccccc}
\hline Tingkat & \multicolumn{2}{c}{ RPI } & \multicolumn{2}{c}{ RM } & \multicolumn{2}{c}{ RS } & \multicolumn{2}{c}{ RE } & \multicolumn{2}{c}{ RH } \\
\cline { 2 - 10 } Pendidikan & Rendah & Tinggi & Rendah & Tinggi & Rendah & Tinggi & Rendah & Tinggi & Rendah & Tinggi \\
\hline SMP & 0 & 2 & 1 & 1 & 1 & 1 & 1 & 1 & 2 & 0 \\
$\%$ & $0,0 \%$ & $100,0 \%$ & $50,0 \%$ & $50,0 \%$ & $50,0 \%$ & $50,0 \%$ & $50,0 \%$ & $50,0 \%$ & $100,0 \%$ & $0,0 \%$ \\
SMU & 26 & 40 & 33 & 33 & 29 & 37 & 34 & 32 & 31 & 35 \\
$\%$ & $39,4 \%$ & $60,6 \%$ & $50,0 \%$ & $50,0 \%$ & $43,9 \%$ & $56,1 \%$ & $51,5 \%$ & $48,5 \%$ & $47,0 \%$ & $53,0 \%$ \\
S1 & 14 & 18 & 15 & 17 & 14 & 18 & 20 & 12 & 15 & 17 \\
$\%$ & $43,8 \%$ & $56,2 \%$ & $46,9 \%$ & $53,1 \%$ & $43,8 \%$ & $56,2 \%$ & $62,5 \%$ & $37,5 \%$ & $46,9 \%$ & $53,1 \%$ \\
\hline
\end{tabular}

Tabel 24

Hasil Uji Crosstab Lama Menggunakan Nasabah BCA

\begin{tabular}{cccccccccccc}
\hline Lama & \multicolumn{3}{c}{ RPI } & \multicolumn{2}{c}{ RM } & \multicolumn{2}{c}{ RS } & \multicolumn{2}{c}{ RE } & \multicolumn{2}{c}{ RH } \\
\cline { 2 - 10 } Menggunakan & Rendah & Tinggi & Rendah & Tinggi & Rendah & Tinggi & Rendah & Tinggi & Rendah & Tinggi \\
\hline$<1$ tahun & 7 & 10 & 6 & 11 & 3 & 14 & 8 & 9 & 8 & 9 \\
$\%$ & $41,2 \%$ & $58,8 \%$ & $35,3 \%$ & $64,7 \%$ & $17,6 \%$ & $82,4 \%$ & $47,1 \%$ & $52,9 \%$ & $47,1 \%$ & $52,9 \%$ \\
$1-2$ tahun & 20 & 32 & 30 & 22 & 25 & 27 & 33 & 19 & 25 & 27 & $51 \%$ \\
$\%$ & $38,5 \%$ & $61,5 \%$ & $57,7 \%$ & $42,3 \%$ & $48,1 \%$ & $51,9 \%$ & $63,5 \%$ & $36,5 \%$ & $48,1 \%$ & $51,9 \%$ \\
$3-4$ tahun & 1 & 7 & 3 & 5 & 7 & 1 & 6 & 2 & 5 & 3 & 6 \\
$\%$ & $12,5 \%$ & $87,5 \%$ & $37,5 \%$ & $62,5 \%$ & $87,5 \%$ & $12,5 \%$ & $75,0 \%$ & $25,0 \%$ & $62,5 \%$ & $37,5 \%$ \\
$4-5$ tahun & 7 & 5 & 4 & 8 & 4 & 8 & 4 & 8 & 5 & 7 \\
$\%$ & $58,3 \%$ & $41,7 \%$ & $33,3 \%$ & $66,7 \%$ & $33,3 \%$ & $66,7 \%$ & $33,3 \%$ & $66,7 \%$ & $41,7 \%$ & $58,3 \%$ \\
$>5$ tahun & 5 & 6 & 6 & 5 & 5 & 6 & 4 & 7 & 5 & 6 \\
$\%$ & $45,5 \%$ & $54,5 \%$ & $54,5 \%$ & $45,5 \%$ & $45,5 \%$ & $54,5 \%$ & $36,4 \%$ & $63,6 \%$ & $45,5 \%$ & $54,5 \%$ \\
\hline
\end{tabular}

Berdasarkan hasil uji crosstab lama menggunakan nasabah BCA pada Tabel 24 menunjukkan bahwa terdapat kesamaan persepsi risiko pada penggunaan $<1$ tahun untuk keseluruhan risiko memiliki kesamaan. Penggunaan 1-2 tahun untuk risiko proses internal (RPI), risiko sistem (RS) dan risiko hukum (RH) memiliki kesamaan, hasil yang berkebalikan ditemukan pada risiko manusia dan risiko eksternal (RE). Nasabah cenderung menganggap risiko tersebut lebih rendah. Pada penggunaan 3-4 tahun terdapat kesamaan untuk risiko 
sistem, risiko eksternal dan risiko hukum, hasil yang berkebalikan ditemukan pada risiko proses internal dan risiko hukum di mana nasabah cenderung memberikan skor tinggi. Untuk penggunaan 4-5 tahun semuanya memiliki kesamaan, namun pada risiko proses internal. Nasabah cenderung menganggap risiko lebih rendah dan untuk penggunaan $>5$ tahun terdapat kesamaan pada risiko proses internal, risiko sistem, risiko eksternal, dan risiko hukum namun hasil yang berkebalikan pada risiko manusia.

\section{Uji Crosstab Nasabah BRI}

Berdasarkan hasil uji crosstab gender nasabah BRI pada Tabel 25 menunjukkan bahwa terdapat kesamaan persepsi risiko di kalangan laki-laki dan perempuan untuk risiko proses internal (RPI), risiko manusia (RM), risiko sistem (RS) dan risiko eksternal (RE), hasil yang berkebalikan ditemukan untuk risiko hukum $(\mathrm{RH})$. Perempuan cenderung menganggap kedua risiko tersebut lebih tinggi dibandingkan laki-laki.

\section{Tabel 25}

Hasil Uji Crosstab Gender Nasabah BRI

\begin{tabular}{ccccccccccc}
\hline \multirow{2}{*}{ Gender } & \multicolumn{2}{c}{ RPI } & \multicolumn{2}{c}{ RM } & \multicolumn{2}{c}{ RS } & \multicolumn{2}{c}{ RE } & \multicolumn{2}{c}{ RH } \\
\cline { 2 - 10 } & Rendah & Tinggi & Rendah & Tinggi & Rendah & Tinggi & Rendah & Tinggi & Rendah & Tinggi \\
\hline Laki-laki & 21 & 23 & 21 & 23 & 22 & 22 & 14 & 30 & 25 & 19 \\
$\%$ & $47,7 \%$ & $52,3 \%$ & $47,7 \%$ & $52,3 \%$ & $50,0 \%$ & $50,0 \%$ & $31,8 \%$ & $68,2 \%$ & $56,8 \%$ & $43,2 \%$ \\
Perempuan & 23 & 33 & 25 & 31 & 28 & 28 & 26 & 30 & 26 & 30 \\
$\%$ & $41,1 \%$ & $58,9 \%$ & $44,6 \%$ & $55,4 \%$ & $50,0 \%$ & $50,0 \%$ & $46,4 \%$ & $53,6 \%$ & $46,4 \%$ & $53,6 \%$ \\
\hline
\end{tabular}

Berdasarkan hasil uji crosstab status pernikahan nasabah BRI pada Tabel 26 menunjukkan bahwa terdapat kesamaan persepsi risiko di kalangan nasabah yang belum menikah dan yang sudah menikah untuk sebagian besar risiko memiliki kesamaan, namun pada risiko hukum (RH) terdapat perbedaan. Nasabah yang belum menikah cenderung menganggap risiko tersebut lebih rendah dibandingkan yang sudah menikah.

Tabel 26

Hasil Uji Crosstab Status Pernikahan Nasabah BRI

\begin{tabular}{cccccccccccc}
\hline \multirow{2}{*}{ Status } & \multicolumn{3}{c}{ RPI } & \multicolumn{2}{c}{ RM } & \multicolumn{2}{c}{ RS } & \multicolumn{2}{c}{ RE } & \multicolumn{2}{c}{ RH } \\
\cline { 2 - 10 } & Rendah & Tinggi & Rendah & Tinggi & Rendah & Tinggi & Rendah & Tinggi & Rendah & Tinggi \\
\hline Menikah & 0 & 1 & 1 & 0 & 1 & 0 & 1 & 0 & 1 & 0 \\
$\%$ & $0,0 \%$ & $100,0 \%$ & $100,0 \%$ & $0,0 \%$ & $100,0 \%$ & $0,0 \%$ & $100,0 \%$ & $0,0 \%$ & $100,0 \%$ & $0,0 \%$ \\
Belum Menikah & 44 & 55 & 45 & 54 & 49 & 50 & 39 & 60 & 50 & 49 \\
$\%$ & $44,4 \%$ & $55,6 \%$ & $45,5 \%$ & $54,5 \%$ & $49,5 \%$ & $50,5 \%$ & $39,4 \%$ & $60,6 \%$ & $50,5 \%$ & $49,5 \%$ \\
\hline
\end{tabular}

Berdasarkan hasil uji crosstab penghasilan nasabah BRI pada Tabel 27 menunjukkan bahwa terdapat kesamaan persepsi risiko di kalangan nasabah dengan penghasilan $<2$ juta dan $2-5$ juta untuk risiko proses internal (RPI), untuk risiko manusia (RM), dan risiko eksternal, hasil yang berkebalikan ditemukan pada risiko sistem (RS) dan risiko hukum (RH). Nasabah berpenghasilan $<2$ juta cenderung menganggap risiko tersebut lebih tinggi.

Tabel 27

Hasil Uji Crosstab Penghasilan Nasabah BRI

\begin{tabular}{cccccccccccc}
\hline \multirow{2}{*}{ Penghasilan } & \multicolumn{3}{c}{ RPI } & \multicolumn{2}{c}{ RM } & \multicolumn{2}{c}{ RS } & \multicolumn{2}{c}{ RE } & \multicolumn{2}{c}{ RH } \\
\cline { 2 - 11 } & Rendah & Tinggi & Rendah & Tinggi & Rendah & Tinggi & Rendah & Tinggi & Rendah & Tinggi \\
\hline 2 juta & 27 & 34 & 30 & 31 & 34 & 27 & 27 & 34 & 34 & 27 \\
$\%$ & $44,3 \%$ & $55,7 \%$ & $49,2 \%$ & $50,8 \%$ & $55,7 \%$ & $44,3 \%$ & $44,3 \%$ & $55,7 \%$ & $55,7 \%$ & $44,3 \%$ \\
$2-5$ juta & 17 & 20 & 16 & 21 & 15 & 22 & 13 & 24 & 17 & 20 & 20 \\
$\%$ & $45,9 \%$ & $54,1 \%$ & $43,2 \%$ & $56,8 \%$ & $40,5 \%$ & $59,5 \%$ & $35,1 \%$ & $64,9 \%$ & $45,9 \%$ & $54,1 \%$ \\
$>5$ juta & 0 & 2 & 0 & 2 & 1 & 1 & 0 & 2 & 0 & 2 \\
$\%$ & $0,0 \%$ & $100,0 \%$ & $0,0 \%$ & $100,0 \%$ & $50,0 \%$ & $50,0 \%$ & $0,0 \%$ & $100,0 \%$ & $0,0 \%$ & $100,0 \%$ \\
\hline
\end{tabular}


Berdasarkan hasil uji crosstab penggunaan per bulan nasabah BRI pad Tabel 28 menunjukkan bahwa terdapat kesamaan persepsi risiko pada penggunaan 1-3 kali untuk risiko manusia (RM), risiko sistem (RS) dan risiko hukum (RH), hasil yang berkebalikan ditemukan pada risiko proses internal (RPI) dan risiko eksternal (RE). Nasabah cenderung menganggap risiko tersebut lebih tinggi. Pada penggunaan 4-6 kali terdapat kesamaan pada keselutuhan risiko. Untuk penggunaan 7-10 kali semuanya memiliki kesamaan, dan untuk penggunaan $>10$ kali terdapat kesamaan pada risiko proses internal, risiko manusia, dan risiko hukum namun hasil yang berkebalikan pada risiko sistem dan risiko eksternal.

Tabel 28

Hasil Uji Crosstab Penggunaan Per Bulan Nasabah BRI

\begin{tabular}{|c|c|c|c|c|c|c|c|c|c|c|}
\hline \multirow{2}{*}{ Penggunaan } & \multicolumn{2}{|c|}{ RPI } & \multicolumn{2}{|c|}{ RM } & \multicolumn{2}{|c|}{$\mathrm{RS}$} & \multicolumn{2}{|c|}{ RE } & \multicolumn{2}{|c|}{ RH } \\
\hline & Rendah & Tinggi & Rendah & Tinggi & Rendah & Tinggi & Rendah & Tinggi & Rendah & Tinggi \\
\hline 1-3 kali & 34 & 37 & 37 & 34 & 37 & 34 & 32 & 39 & 39 & 32 \\
\hline$\%$ & $47,9 \%$ & $52,1 \%$ & $52,1 \%$ & $47,9 \%$ & $52,1 \%$ & $47,9 \%$ & $45,1 \%$ & $54,9 \%$ & $54,9 \%$ & $45,1 \%$ \\
\hline 4-6 kali & 4 & 9 & 4 & 9 & 3 & 10 & 3 & 10 & 6 & 7 \\
\hline$\%$ & $30,8 \%$ & $69,2 \%$ & $30,8 \%$ & $69,2 \%$ & $23,1 \%$ & $76,9 \%$ & $23,1 \%$ & 76,9 & $46,2 \%$ & $53,8 \%$ \\
\hline $7-10$ kali & 4 & 5 & 3 & 6 & 4 & 5 & 0 & 9 & 4 & 5 \\
\hline$\%$ & $44,4 \%$ & $55,6 \%$ & $33,3 \%$ & $66,7 \%$ & $44,4 \%$ & $55,6 \%$ & $0,0 \%$ & $100,0 \%$ & $44,4 \%$ & $55,6 \%$ \\
\hline$>10$ kali & 2 & 5 & 2 & 5 & 6 & 1 & 5 & 2 & 2 & 5 \\
\hline$\%$ & $28,6 \%$ & $71,4 \%$ & $28,6 \%$ & $71,4 \%$ & $85,7 \%$ & $14,3 \%$ & $71,4 \%$ & $28,6 \%$ & $28,6 \%$ & $71,4 \%$ \\
\hline
\end{tabular}

Berdasarkan hasil uji crosstab tingkat pendidikan nasabah BRI pada Tabel 29 menunjukkan bahwa terdapat kesamaan persepsi risiko pada tingkat pendidikan untuk risiko proses internal (RPI), untuk risiko manusia $(\mathrm{RM})$, dan risiko eksternal (RE), hasil yang berkebalikan ditemukan pada risiko sistem (RS) dan risiko hukum (RH). Nasabah dengan tingkat pendidikan SMU cenderung menganggap risiko tersebut lebih tinggi dibandingkan dengan $\mathrm{S} 1$.

Tabel 29

Hasil Uji Crosstab Tingkat Pendidikan Nasabah BRI

\begin{tabular}{ccccccccccc}
\hline \multirow{2}{*}{ Tingkat Pendidikan } & \multicolumn{2}{c}{ RPI } & \multicolumn{2}{c}{ RM } & \multicolumn{2}{c}{ RS } & \multicolumn{2}{c}{ RE } & \multicolumn{2}{c}{ RH } \\
\cline { 2 - 10 } & Rendah & Tinggi & Rendah & Tinggi & Rendah & Tinggi & Rendah & Tinggi & Rendah & Tinggi \\
\hline SMU & 31 & 32 & 30 & 33 & 30 & 33 & 24 & 39 & 28 & 35 \\
$\%$ & $49,2 \%$ & $50,8 \%$ & $47,6 \%$ & $52,4 \%$ & $47,6 \%$ & $52,4 \%$ & $38,1 \%$ & $61,9 \%$ & $44,4 \%$ & $55,6 \%$ \\
S1 & 13 & 24 & 16 & 21 & 20 & 17 & 16 & 21 & 23 & 14 \\
$\%$ & $35,1 \%$ & $64,9 \%$ & $43,2 \%$ & $56,8 \%$ & $54,1 \%$ & $45,9 \%$ & $43,2 \%$ & $56,8 \%$ & $62,2 \%$ & $37,8 \%$ \\
\hline
\end{tabular}

Berdasarkan hasil uji crosstab lama menggunakan nasabah BRI pada Tabel 30 menunjukkan bahwa terdapat kesamaan persepsi risiko pada penggunaan $<1$ tahun untuk keseluruhan risiko memiliki kesamaan namun untuk risiko hukum terdapat hasil yang berbeda. Penggunaan 1-2 tahun untuk risiko proses internal (RPI), risiko sistem (RS) dan risiko eksternal (RE) memiliki kesamaan, hasil yang berkebalikan ditemukan pada risiko manusia dan risiko manusia (RM) dan risiko hukum (RH).

Nasabah cenderung menganggap risiko tersebut lebih rendah. Pada penggunaan 3-4 tahun terdapat kesamaan pada keseluruhan risiko. Untuk penggunaan 4-5 tahun semuanya memiliki kesamaan, namun pada risiko hukum. Nasabah cenderung menganggap risiko lebih rendah dan untuk penggunaan > 5 tahun terdapat kesamaan pada risiko proses internal, risiko manusia, risiko sistem, dan risiko eksternal, namun hasil yang berkebalikan pada risiko hukum.

Tabel 31 menunjukkan bahwa persepsi nasabah BRI dan BCA berbeda pada risiko hukum untuk semua variable demografi. Sebaliknya persamaan persepsi nasabah kedua bank banyak terjadi untuk risiko proses internal. Dalam hal lama menggunakan, nasabah kedua bank berbeda persepsi untuk semua jenis risiko operasional. 
Tabel 30

Hasil Uji Crosstab Lama Menggunakan Nasabah BRI

\begin{tabular}{cccccccccccc}
\hline \multirow{2}{*}{ Lama Menggunakan } & \multicolumn{3}{c}{ RPI } & \multicolumn{2}{c}{ RM } & \multicolumn{2}{c}{ RS } & \multicolumn{2}{c}{ RE } & \multicolumn{2}{c}{ RH } \\
\cline { 2 - 10 } & Rendah & Tinggi & Rendah & Tinggi & Rendah & Tinggi & Rendah & Tinggi & Rendah & Tinggi \\
\hline < tahun & 12 & 13 & 16 & 9 & 16 & 9 & 15 & 10 & 14 & 11 \\
$\%$ & $48,0 \%$ & $52,0 \%$ & $64,0 \%$ & $36,0 \%$ & $64,0 \%$ & $36,0 \%$ & $60,0 \%$ & $40,0 \%$ & $56,0 \%$ & $44,0 \%$ \\
$1-2$ tahun & 17 & 22 & 20 & 19 & 18 & 21 & 9 & 30 & 21 & 18 & 9 \\
$\%$ & $43,6 \%$ & $56,4 \%$ & $51,3 \%$ & $48,7 \%$ & $46,2 \%$ & $53,8 \%$ & $23,1 \%$ & $76,9 \%$ & $53,8 \%$ & $46,2 \%$ \\
$3-4$ tahun & 9 & 8 & 5 & 12 & 8 & 9 & 7 & 10 & 4 & 13 & 4 \\
$\%$ & $52,9 \%$ & $47,1 \%$ & $29,4 \%$ & $70,6 \%$ & $47,1 \%$ & $52,9 \%$ & $41,2 \%$ & $58,8 \%$ & $23,5 \%$ & $76,5 \%$ \\
$4-5$ tahun & 3 & 8 & 2 & 9 & 5 & 6 & 5 & 6 & 6 & 5 \\
$\%$ & $27,3 \%$ & $72,7 \%$ & $18,2 \%$ & $81,8 \%$ & $45,5 \%$ & $54,5 \%$ & $45,5 \%$ & $54,5 \%$ & $54,5 \%$ & $45,5 \%$ \\
$>5$ tahun & 3 & 5 & 3 & 5 & 3 & 5 & 4 & 4 & 6 & 2 \\
$\%$ & $37,5 \%$ & $62,5 \%$ & $37,5 \%$ & $62,5 \%$ & $37,5 \%$ & $62,5 \%$ & $50,0 \%$ & $50,0 \%$ & $75,0 \%$ & $25,0 \%$ \\
\hline
\end{tabular}

Tabel 31

Hasil Rekapitulasi Uji Crosstab

\begin{tabular}{cccccccccccc}
\hline \multirow{2}{*}{ FD } & \multicolumn{2}{c}{ RPI } & \multicolumn{2}{c}{ RM } & \multicolumn{2}{c}{ RS } & \multicolumn{2}{c}{ RE } & \multicolumn{2}{c}{ RH } \\
\cline { 2 - 10 } & BCA & BRI & BCA & BRI & BCA & BRI & BCA & BRI & BCA & BRI \\
\hline Gender & $=$ & $=$ & $\neq$ & $=$ & $=$ & $=$ & $=$ & $=$ & $\neq$ & $\neq$ \\
Status & $=$ & $=$ & $=$ & $\neq$ & $=$ & $\neq$ & $=$ & $\neq$ & $\neq$ & $=$ \\
Penghasilan & $=$ & $=$ & $\neq$ & $=$ & $\neq$ & $\neq$ & $\neq$ & $=$ & $\neq$ & $\neq$ \\
penggunaan Per Bulan & $\neq$ & $=$ & $\neq$ & $\neq$ & $\neq$ & $\neq$ & $\neq$ & $\neq$ & $\neq$ & $\neq$ \\
Tingkat Pendidikan & $=$ & $=$ & $=$ & $=$ & $=$ & $\neq$ & $=$ & $=$ & $\neq$ & $\neq$ \\
Lama Menggunakan & $\neq$ & $\neq$ & $\neq$ & $\neq$ & $\neq$ & $\neq$ & $\neq$ & $\neq$ & $\neq$ & $\neq$ \\
\hline
\end{tabular}

Keterangan:

Sama : $=$

Berbeda : $\neq$

\section{Simpulan, Keterbatasan, dan Saran}

Berdasarkan hasil penelitian di atas, maka dapat ditarik kesimpulan sebagai berikut: Dapat disimpulkan bahwa sebagian besar nasabah pada Bank Central Asia dan Bank Rakyat Indonesia tidak setuju jika internet banking memiliki risiko operasional yang tinggi; Dapat dilihat dari tabel statistic deskriptif Bank Central Asia dan Bank Rakyat Indonesia pada variabel risiko manusia, risiko sistem dan risiko eksternal terdapat sebagian responden yang memiliki nilai rata-rata netral. Ada sebagian nasabah yang merasakan adanya risiko dalam penggunaan internet banking terhadap risiko-risiko tersebut; Dapat dilihat pada tabel statistik deskriptif nilai rata-rata keseluruhan Bank Central Asia adalah 3,72 dan Bank Rakyat Indonesia 3,64, maka dapat dikatakan dari kedua bank tersebut Bank Central Asia memiliki nilai rata-rata lebih tinggi dari Bank Rakyat Indonesia, maka dapat ditarik simpulan bahwa Bank Central Asia lebih tidak berisiko dalam penggunaan internet banking daripada Bank Rakyat Indonesia; Pada data keseluruhan dapat diketahui bahwa pada umumnya Bank Central Asia lebih dipercaya daripada Bank Rakyat Indonesia karena memiliki skor lebih tinggi dan memiliki efek positif pada segala aspek, namun pada beberapa item Bank Central Asia memiliki skor rendah dan memiliki efek negatif.

Keterbatasan dalam penelitian ini adalah, beberapa rumusan pertanyaan dalam kuesioner ada yang kurang tepat untuk ditanyakan kepada nasabah pada variabel risiko manusia seperti: Permasalahan kesehatan dan keselamatan kerja; Perputaran karyawan yang tinggi; Sengketa antar karyawan; Penipuan internal.

Berdasarkan hasil penelitian dan kesimpulan di atas, maka dapat diberikan saran sebagai berikut: Bagi bank, Penelitian ini memberikan informasi bagi Bank Central Asia kemungkinan perlu melihat risiko operasional yang terjadi, seperti masalah penipuan internal, gangguan pelayanan, dan kegagalan perjanjian outsourcing, sedangkan untuk Bank Rakyat Indonesia perlu melihat sengketa antar karyawan dan penipuan dari luar. Dengan adanya penelitian ini diharapkan dapat memberikan informasi pada pihak bank dalam hal memitigasi kemungkinan risiko yang akan terjadi pada penggunaan 
layanan internet banking; Bagi nasabah, penelitian ini memberikan informasi bahwa penggunaan layanan internet banking tidak memiliki risiko operasional yang tinggi untuk digunakan, tapi kemungkinan akan terjadinya risiko itu sendiri ada, dan diharapkan nasabah dapat berhati-hati dalam menggunakan layanan internet banking; Bagi penelitian selanjutnya disarankan bagi penelitian selanjutnya untuk menambah variabel penelitian, tidak hanya memfokuskan pada internet banking, namun masih ada produk digital banking yang lainnya seperti mobile banking, phone banking, dan sms banking.

\section{Referensi}

Cahyaningrum, A. D., \& Atahau, A. D. R. (2020). Intellectual capital and financial performance: Banks' risk as the mediating variable. Jurnal Manajemen dan Kewirausahaan, 22(1), 21-32.

Darmadi, H. (2013). Metode penelitian pendidikan dan sosial. Bandung: Alfabeta.

Davis, F. D. (1989). Perceived usefulness, perceived ease of use, and user acceptance of information technology. MIS Quarterly, 13(5), 319-339.

Fasa, M. I., Saefullah, \& Wati, A. (2016). Manajemen resiko perbankan syariah di Indonesia. Li Falah Jurnal Studi Ekonomi Dan Bisnis Islam, I(2), 36-53.

Fuad, H. (2017). Pengguna e-banking meningkat tajam. Sindonews.com. Diakses dari https://ekbis. sindonews.com/berita/1172393/178/pengguna-e-banking-meningkat-tajam

Nasri, W., \& Charfeddine, L. (2012). Factors affecting the adoption of internet banking in Tunisia: An integration theory of acceptance model and theory of planned behavior. The Journal of High Technology Management Research, 23(1), 1-14.

Nugraha, I. S., \& Atahau, A. D. R. (2018). The use analysis of internet banking among smes entrepreneurs. Jurnal Keuangan Dan Perbankan, 22(3), 542-556.

Peraturan Bank Indonesia No. 11/25/PBI/2009 tentang perubahan atas PBI No.5/8/PBI/2003 tentang penerapan manajemen risiko bagi bank umum atau bank konvensional.

Peraturan Bank Indonesia No. 11/22/PBI/2010 tentang perubahan atas PBI Nomor 5/8/PBI/2003 tentang penerapan manajemen risiko.

Rao, P. (1996). Measuring consumer perceptions through factor analysis. The Asian Manager (February-March).

Sakti, M. A. J., Achsani, N. A., \& Syarifuddin, F. (2018). Online banking implementation: Risk mapping using erm approach. Bulletin of Monetary Economics and Banking, 20(3), 1-28. https:// doi.org/10.21098/bemp.v20i3.824

Sujarweni, V. W. (2007). SPSS untuk penelitian skripsi. Yogyakarta: Ardana Media.

Sunarjo, \& Yuniarti, S. (2017). Sistem pengendalian risiko operasional pada bank perkreditan rakyat dengan pendekatan indikator dasar. Jurnal Keuangan dan Perbankan, 21(1), 96-104 